\title{
PRODUCTIVITY, OUTPUT, AND FAILURE: A COMPARISON OF TAIWANESE AND KOREAN MANUFACTURERS
}

\author{
Bee Yan Aw \\ Sukkyun Chung \\ Mark J. Roberts \\ Working Paper 8766 \\ http://www.nber.org/papers/w8766 \\ NATIONAL BUREAU OF ECONOMIC RESEARCH \\ 1050 Massachusetts Avenue \\ Cambridge, MA 02138 \\ February 2002
}

The views expressed herein are those of the authors and not necessarily those of the National Bureau of Economic Research.

(C) 2002 by Bee Yan Aw, Sukkyun Chung and Mark J. Roberts. All rights reserved. Short sections of text, not to exceed two paragraphs, may be quoted without explicit permission provided that full credit, including (C) notice, is given to the source. 
Productivity, Output, and Failure: A Comparison of Taiwanese and Korean Manufacturers Bee Yan Aw, Sukkyun Chung and Mark J. Roberts

NBER Working Paper No. 8766

February 2002

JEL No. D2, L0

\begin{abstract}
Industry cost and demand conditions can vary across countries leading to differences in industry market structure, including the distribution of output and productivity across firms and the magnitude of entry and exit flows. It has been argued that despite many outward similarities, two of the most successful Southeast Asian economies, Taiwan and South Korea, differ systematically in the nature of entry costs, the competitiveness of output markets, and the working of their capital markets. In this paper we use micro panel data for producers in seven two-digit manufacturing industries in South Korea and Taiwan and identify a number of systematic differences in industry structure between the two countries. Our empirical findings indicate that, relative to their counterparts in Korea, Taiwanese industries are characterized by less concentrated market structure, more producer turnover, smaller within-industry productivity dispersion across producers, a smaller percentage of plants operating at low productivity levels, and smaller productivity differentials between surviving and failing producers. These patterns are consistent with strong competitive pressures in Taiwan that lead to market selection based on productivity differences. In contrast, the patterns in Korea are consistent with the presence of some impediments to exit or entry that insulate inefficient producers from market pressures.
\end{abstract}

Bee Yan Aw

Department of Economics

Pennsylvania State University

University Park, PA 16802

byr@psu.edu
Sukkyun Chung

Ministry of Information and

Communication

Seoul 110-760

Republic of Korea

schung@mic.go.kr
Mark J. Roberts

Department of Economics

Pennsylvania State University

University Park, PA 16802

and NBER

mroberts@psu.edu 


\section{Introduction}

The rapid economic growth of the Newly Industrializing Countries in East Asia has been a focus of interest for academics and policy makers for two decades. The bulk of the research in this area focuses on key features shared by these countries, such as their strong orientation towards the export market and their high rates of capital investment, and relies on evidence derived from aggregate or sectoral data. ${ }^{\square}$ However, it has also been frequently noted that across these countries there are a number of significant differences in the organization of their industry and ownership structure of their firms. ${ }^{\text {G }}$ For example, in the case of the two most prominent East Asian NICs, Taiwan and Korea, the manufacturing sector in the former is dominated by small and medium-sized enterprises while Korea's large business groups (chaebols) control much of the country's manufacturing output. The relationship between market structure and the performance of these economies, in general, and micro-level performance, in particular, has been less clearly identified.

In this paper we use micro data for seven key manufacturing industries in Taiwan and Korea to quantify several relationships between market structure, producer turnover, and productivity at the micro level. The organizing framework for our inquiry is a class of theoretical models of industry dynamics that have been developed to explain the diverse patterns of firm growth and exit observed in micro data. They recognize that producers within an industry have idiosyncratic differences in their efficiency and profitability. This underlying

\footnotetext{
${ }^{1}$ A number of recent studies based on aggregate and sectoral level data have focused on the role of productivity growth and capital accumulation as determinants of this growth. Krugman (1994), and Rodrik (1995) are among the many researchers that emphasize capital accumulation while others, including Page (1994) and the World Bank (1993) emphasize productivity growth as the principal source of success in these East Asian countries.

${ }^{2}$ Levy (1991) traces the differences in market structure to variations in the costs of market transactions in the initial stages of industrialization, while Martins (1992), Rodrik (1993), and Feenstra, Yang, and Hamilton (1999) examine their impact on trade patterns.
} 
profit heterogeneity, when embedded in a market framework, generates a size distribution of producers, a distribution of productivity or profitability across producers, an endogenous exit decision for incumbent producers that is based on their productivity, and an endogenous flow of new entering firms. A key parameter in many of these models is the sunk cost that must be incurred by a new firm entering the market. This cost acts as a barrier to entry but also insulates inefficient producers from market pressure. An increase in the entry cost results in lower exit probabilities for inefficient producers and less reallocation of output from inefficient to more efficient producers over time, a more concentrated industry structure, and less producer turnover.

Scholars who have discussed the market structure of these two countries have emphasized the greater reliance on market transactions in Taiwan relative to Korea. Pack (1992) and Levy and Kuo (1991) argue that the magnitude of up-front investment required either to construct production facilities or to gather specialized market information is less in Taiwan. They contend that these differences in entry costs induce Taiwanese firms to initiate production at a much smaller size than Korean firms. In addition, Levy (1991) discusses the reliance on subcontracting relationships among Taiwanese producers. The presence of a well-developed network of subcontractors in several key industries in Taiwan works to reduce the cost of entry by allowing firms to enter at small scale without a serious cost disadvantage. More recently, Feenstra, Hamilton, and Huang (2001) argue that the contrast in the intensity of business networks in the two economies is more than just a simple reflection of market or state forces, but ultimately affects industry performance.

Our empirical results demonstrate systematic differences in the relationship between exit, productivity, and output for many manufacturing industries in Korea and Taiwan. Korean industries are characterized by less producer turnover, more cross-sectional productivity 
dispersion among producers, a slightly more concentrated market structure, larger productivity differentials between surviving and failing producers, and a larger percentage of plants located in the lower tail of the productivity distribution. All of these patterns are consistent with impediments to entry or exit that act to insulate inefficient producers from market pressures in Korea.

The remainder of the paper is divided into five sections. In the next section, we summarize the theoretical framework. In section three, we discuss the micro data sets from the Korean and Taiwanese Census of Manufactures and describe our methodology for measuring total factor productivity for each producer. The fourth section analyzes the relationships between the cross-sectional distributions of output and productivity in each of seven industries in Taiwan and Korea. In section five we use the time-series elements of our data and focus on the relationships between producers' productivity, size, and exit patterns. In the final section we summarize the major findings and conclusions.

\section{The Theoretical Framework: Productivity, Size, and Turnover}

Theoretical models of industry dynamics by Jovanovic (1982), Lambson (1991), Hopenhayn (1992), and Ericson and Pakes (1995) have been developed to explain the divergent paths of growth and failure that characterize micro data on individual producers. While each of these models differs in particular details, they have a number of important similarities including a source of persistent profit heterogeneity across producers and a source of random shocks that lead to fluctuations in each producer's profits over time. Each producer makes an exit decision based on their current profit conditions and knowledge of the stochastic process generating future profits. Given a decision to continue in business, each producer then makes an output 
decision. The models produce a description of the set of producers in operation at a point in time and the distributions of output and profits across the producers. They can be used as a basis for explaining differences in market structure, exit rates, and producer heterogeneity across countries, time periods, or industries.

In this paper we will focus on differences in two-digit manufacturing industries between Taiwan and South Korea. To organize our empirical analysis we will rely on the model of firm dynamics developed by Hopenhayn (1992). In this model an industry is composed of a continuum of price-taking firms that produce a homogeneous output. Firms are heterogeneous in terms of their efficiency, with each firm's output depending on input levels and a random productivity shock, $\phi$. This productivity shock follows a Markov process that is independent across firms. The distribution of future productivity for each firm is represented by the distribution function $F\left(\phi_{t+1} \mid \phi_{t}\right)$ which is strictly decreasing in $\phi_{t}$, implying that, relative to a low-productivity firm, a high-productivity firm in year $t$ has a larger probability of having high productivity in year $t+1$. Each incumbent firm knows its current productivity and the distribution function $F$.

At the start of each time period, before its productivity level for that period is observed, each firm makes a decision to participate in the market or not. Incumbent firms have two choices: they may choose to exit the industry or remain in the industry. If they exit they earn a scrap value for their plant. If they remain in, they pay a fixed $\cos t C_{f}$ after which they observe their productivity shock and choose their output level for that period. Potential entrants can enter by paying a sunk entry cost, $C_{e}$, after which they draw their initial productivity level $\phi$ from a common distribution function $G(\phi)$, and choose their output level. Input and output prices in the industry are determined competitively to clear the respective markets. 
The endogenous variables produced by the model are the flow of entrants into the market in each period and the minimum level of productivity required for incumbents to stay in the market. The flow of entrants is determined so that the expected profits of an entrant equal the sunk entry cost. The failure boundary, which we denote by $X$, is the lowest level of productivity , $\phi$, that will enable the firm to have positive discounted expected profits over future periods. Firms with current productivity less than $X$ will choose to exit the market and those with current productivity greater than $X$ will choose to remain in.

The theoretical framework has an important role for sunk entry costs, $C_{e}$. Specifically, if $C_{e}$ is not too large and demand is stable, industry equilibrium will involve simultaneous offsetting flows of entering and exiting firms, and changes in the level of entry cost will affect the magnitude of these flows. Hopenhayn demonstrates that a higher $C_{e}$ will raise the level of discounted profits needed to make entry profitable, thus discouraging entry. In addition, a higher $C_{e}$ will also lower the minimum productivity level $X$ needed for incumbents to survive, thus reducing the amount of firm exit. High sunk entry costs provide a barrier to the entry of new firms and thus insulate incumbents from the effects of market selection. Alternatively, low sunk entry costs produce high levels of firm turnover and demanding requirements on the productivity of incumbent firms. In this model, sunk entry costs are a key determinant of both producer turnover and the distribution of efficiency levels and output across incumbent producers in the industry.

Using the micro data sets developed in the next section we can summarize several aspects of an industry's turnover, productivity distribution, and output distribution and compare these characteristics for the same industry in Korea and Taiwan. The model predicts that exit will be concentrated among the producers with the lowest current productivity. We can empirically test 
this prediction in our data by examining producers in period $t$ and asking if there are systematic productivity differences between the group that exits the market after period $t$ and the group that survives into period $t+1$. We can further refine this prediction to recognize the role that sunk entry costs play in the failure process. The theory model predicts that high entry costs weaken the pressure of market selection on incumbents and will result in the survival of more lowproductivity producers in the industry. Related to this is that the productivity differential between exiting firms and surviving firms will be larger as sunk entry costs increase. This occurs because the reduction in the failure boundary $X$ means that exiting firms will be more heavily concentrated in the low-productivity tail of the distribution when entry costs are high. By comparing the productivity differentials between surviving and failing producers in an industry we will be able to tell if the patterns observed in Korea are consistent with higher entry costs than the patterns in Taiwan. We will provide several comparisons of the productivity distribution that are designed to quantify differences between exiting and surviving firms.

A second implication of the theory is that high entry costs should result in lower producer turnover and we can directly compare the turnover rate for an industry across the two countries. Third, the theory makes some predictions about the output distribution across firms. Industries with high entry costs will have less entry and a higher market price. This will result in a higher output level for firms conditional on their efficiency level $\phi$. Offsetting this is the fact that more firms with a low level of $\phi$ will be able to survive, so the overall effect on the size distribution is ambiguous. We can examine the net effect of these two forces by comparing the market share of producers sorted by their productivity levels. A higher concentration of industry output resulting from firms in the lower tail of the productivity distribution is consistent with weaker market selection and the survival of more low-productivity producers. 


\section{Micro Data and Productivity Measurement \\ Census of Manufactures Data}

The data sets used in our empirical analysis are collected as part of the manufacturing censuses taken every five years in Taiwan and Korea. $\square$ We will focus on seven two-digit manufacturing industries: textiles, apparel, chemicals, plastics, fabricated metals, electrical machinery and electronics, and transportation equipment. These represent the key traditional industries that both countries relied upon for their early export market development and key modern industries that have played an increasingly important role in each country's exports in recent years. With the exception of apparel, all of these industries have had substantial output growth during the 1980's, the decade we study. These industries account for at least 54 percent of manufacturing output in each year of our data in Taiwan and at least 53 percent in Korea.

In the Korean data, the observations are for manufacturing plants with five or more employees in the census years, 1983, 1988 and 1993. In the case of Taiwan, observations are at the firm level for the three census years, 1981, 1986 and 1991. In each case the micro observations are linked across the three census years so we can identify entering and exiting producers in each year. Ideally, we would like comparisons of the size and productivity distributions to be based on micro observations for the same units, either plants or firms. Unfortunately for our purposes, the manufacturing censuses in the two countries are not conducted with the same sampling unit. However, since the vast majority of firms in Taiwan are single-plant producers, the distinction between plant and firm is not as important as in other

\footnotetext{
${ }^{3}$ The collection of the data contained in the industrial censuses of Taiwan comes under the jurisdiction of the Directorate-General of Budget, Accounting and Statistics, Executive Yuan. The data at the firm level is aggregated and published as separate volumes entitled, The Report on Industrial and Commercial Census Taiwan-Fukien Area, The Republic of China. The National Statistical Office of the Republic of Korea collects the plant-level data contained in the industrial census. The plant-level data is aggregated to the industry level and published in separate volumes entitled, Report on Industrial Census (Whole Country).
} 
countries. The difference in sampling unit will tend to underestimate the size of Korean producers relative to their counterparts in Taiwan, and that must be recognized when interpreting our findings. To simplify the discussion we will refer to the data as being plant-level for both countries, even though only firm-level information is available for Taiwan. Finally, in order to make comparisons of the size distributions in the two countries more comparable, we limit our analysis to firms in Taiwan that have five or more employees. This corresponds to the size cutoff imposed in the Korean data. It eliminates between 39 and 44 percent of the firm observations in each of the three years, but only between 2.8 and 3.2 percent of industry output in any year.

\section{Total Factor Productivity Index}

The data collected in each country is similar, and contains variables that are commonly collected in micro data sets based on producer surveys. The value of output produced in the plant, expenditure on intermediate materials, employment levels, expenditure on labor, and the book value of the capital stock are the primary variables we use to construct an index of total factor productivity $(T F P)$ for each plant. The index is used as a single measure of the plant's relative efficiency in a year, a proxy for $\phi$, in the theoretical model. A TFP index captures many factors that can lead to profit differences across plants, including differences in technology, age or quality of the capital stock, managerial ability, scale economies combined with differences in size, or differences in output quality. Our interest is in the relationship between this broad-based performance measure and the plant's output and exit decision.

\footnotetext{
${ }^{4}$ Since the plants with less than five employees are not surveyed in the Korean census we do not know how many producers are eliminated by this sampling cutoff in Korea.
} 
As our index of TFP we adopt the multilateral index developed by Caves, Christensen and Diewert (1982) and extended by Good, Nadiri, and Sickles (1997). The productivity index is calculated separately for each of the seven two-digits industries in each country. The multilateral index relies on a single reference point that is constructed as a hypothetical plant that has the arithmetic mean values of $\log$ output, log input, and input cost shares over all plants in the twodigit industry/country in each year. Each plant's logarithmic output and input levels are measured relative to this reference point in each year and then the reference points are chainlinked over time.

The total factor productivity index for plant $i$ in year $t$ is defined as:

$$
\begin{aligned}
\ln T F P_{t}^{i}=\left(\ln Q_{t}^{i}-\overline{\ln Q_{t}}\right)+\sum_{s=2}^{t}\left(\overline{\ln Q}_{s}-\overline{\ln Q_{s-1}}\right) \\
-\left[\sum_{j} \frac{1}{2}\left(\alpha_{t j}^{i}+\bar{\alpha}_{t j}\right)\left(\ln X_{t j}^{i}-\overline{\ln X_{t j}}\right)+\sum_{s=2}^{t} \sum_{j} \frac{1}{2}\left({\overline{\alpha_{s j}}}+{\overline{\alpha_{s-1 j}}}\right)\left(\overline{\ln X}_{s j}-\overline{\ln X}_{s-1 j}\right)\right]
\end{aligned}
$$

$\ln Q_{t}^{i}, \ln X_{t j}^{i}$, and $\alpha_{t j}^{i}$ are the $\log$ output, $\log$ input of factor $j$, and the cost share of factor $j$ for plant $i . \overline{\ln Q_{t}}, \overline{\ln X_{t j}}$, and $\overline{\alpha_{t j}}$ are the same variables for the hypothetical reference plant in the industry in year $t$ and are equal to the arithmetic mean of the corresponding variable over all plants in the year. The first term of the first line in the above equation is the deviation of the plant's output from the output of the reference point in the industry in year $t$, and the second term is the cumulative change in the output reference point between year $t$ and the initial year, $t=1$. The two terms in the second line perform the same operation for each factor input $j$, and are weighted by the average of the cost shares for plant $i$ and the reference point in year $t$. The index measures total factor productivity of each plant in each year relative to that of the hypothetical 
plant in the initial year. This productivity index is particularly useful in analyzing the crosssectional distribution of plant productivity levels for an industry in one of the countries and the movement of this distribution over time ${ }^{5}$ Because the index measures only the relative productivity of the plants in an industry, it cannot be used to make productivity comparisons across industries or across countries for a single industry. ${ }^{\mathrm{b}}$ When we make productivity comparisons between Korea and Taiwan for an industry we will not compare the levels of productivity in the two countries but rather focus on the shape of the productivity distribution across plants within each of the countries.

\section{Cross-Section Distribution of Output and Productivity}

We begin by summarizing the distribution of gross output by plant size, measured in terms of three employment categories: 5-99 workers, 100-499 workers, and 500 plus workers. These figures are reported for 1986 in Taiwan and 1988 in Korea in Table 1. In every industry, the largest size category of plants account for larger shares of total industry output in Korea than in Taiwan. This difference is largest in transportation equipment and fabricated metals. On average, plants employing 500 or more workers contribute 51.8 percent of total industry output in Korea and 35.4 percent in Taiwan. At the other end of the size spectrum, plants in the smallest employment category in six of the seven industries account for larger shares of total output in Taiwan compared to Korea, averaging 33.6 percent and 21 percent of total output,

\footnotetext{
${ }^{5}$ Aw, Chen, and Roberts (2001) summarize the cross-sectional productivity distributions for a few of these Taiwanese industries using kernel density estimators. The distributions are generally symmetric, bell-shaped distributions with long tails. For most of the industries they shift systematically to the right over time reflecting a widespread increase in total factor productivity for producers.

${ }^{6}$ The index can be used to make across-country comparisons for a single industry if the researcher has appropriate deflators for output in each country. The deflators must recognize the differences in the composition of output in each country. We do not have price deflators that do this and instead construct the productivity index as a measure of plant efficiency relative to other plants in the same industry and country.
} 
respectively. This general pattern is consistent with results reported by Levy and Kuo (1991) and Levy (1991).

The models of industry dynamics rely on underlying differences in efficiency to generate differences in producer size and turnover. With our data we can directly measure the crosssection distribution of productivity in each industry. Table 2 presents two measures of withinindustry cross-sectional dispersion in the productivity index $\ln T F P$. The table reports the standard deviation and the range between the $10^{\text {th }}$ and $90^{\text {th }}$ percentiles of the plant-level distribution by industry and country. The summary statistics are averaged over the three census years in each country.

Both dispersion measures are higher in Korea than in Taiwan in every one of the seven industries. The largest differences in magnitude between Taiwan and Korea occur in the chemicals, textiles, and apparel industries. The industries with the smallest difference in dispersion, measured by either the standard deviation or percentile range, are plastics and transportation. These results imply that there is much more heterogeneity in productivity among plants in Korea than in Taiwan. The higher dispersion in Korea relative to Taiwan is independent of the average growth in TFP across the seven industries in the two countries as indicated in Table 2. Taiwanese industries with very high as well as very low TFP growth rates relative to those in Korea, all have dispersion measures that are lower than their counterparts in Korea.

\footnotetext{
${ }^{7}$ The figures presented in these papers, as in ours, underestimate the difference in firm concentration between Korea and Taiwan. First, producers with less than five workers are not included in these calculations because they are not included in the Korea dataset we utilize. Firms in this size range account for almost half of the total number of manufacturing firms in Taiwan but are much less common in Korea. Second, as mentioned above, the Korean industrial census data we utilize in Table 1 is collected at the plant level rather than the firm level as in Taiwan. For both these reasons, the actual concentration of output in the hands of large firms in Korea would be even higher than the numbers in Table 1 indicate.
} 
One possible reason for the larger variance in productivity in Korea is that higher entry and exit costs result in the survival of more relatively low-productivity plants in the industry. We can examine this by summarizing the distribution of the number of plants and plant output by relative productivity level. In the left half of Figure 1, we plot the share of the number of plants against the percentage deviation of plant TFP from the industry-country mean TFP. In every industry we observe that the plant line for Korea lies above the line for Taiwan at low levels of productivity (roughly, productivity levels below the mean). This implies that, relative to Taiwan, a higher percentage of plants in Korea are concentrated in the lower tail of the productivity distribution. This difference is particularly large in the textiles, apparel, and chemicals industries, the three industries with the largest difference in productivity dispersion between the two countries. This pattern, which shows that a larger percentage of the industry's plants are at a productivity disadvantage in Korea, is consistent with weaker market selection forces and a lower threshold level of productivity needed for survival.

The graphs in the right half of Figure 1 show how the cumulative market share of the plants varies with the plant productivity level. Two features stand out. First, for productivity levels below the mean, the curves for Taiwan and Korea are very similar for all but two of the seven industries. This implies that the cumulative output contribution of plants at low productivity levels is similar across the two countries. In the other two industries, chemicals and plastics, plants with relatively low levels of productivity are responsible for a larger share of output in Korea than in Taiwan. Second, at the highest productivity levels, the cumulative output distribution in Korea lies below the level of Taiwan. This implies that output in Korea is more skewed toward plants in the high end of the productivity distribution. While Korea has a larger concentration of plants in the lower tail of the productivity distribution, the effect of firm size 
distribution on aggregate productivity is offset by the higher concentration of output in plants in the highest tail of the productivity distribution.

To summarize, the data indicate that Korean industries have much larger dispersion in plant productivity than the same industry in Taiwan. This wider dispersion in Korea is accompanied by a higher concentration of plants with relatively low productivity levels. However, the higher concentration of plants does not translate into a higher concentration of output in the low-productivity tail of the distribution. The cumulative distribution of output is similar in Korea and Taiwan for plants with productivity below the industry mean. In fact, the relatively high-productivity plants in Korea tend to account for a larger fraction of industry output than their high-productivity counterparts in Taiwan. In short, relative to Taiwan, most of the Korean industries have a higher percentage of their plants operating at low productivity levels but a higher percentage of their output coming from their high-productivity plants. These patterns are largely consistent with the predictions of the market selection theory. Higher initial investment costs and sunk costs of entry can combine to weaken market selection forces in Korea and result in the survival of more low-productivity plants in the Korean industries.

\section{Turnover and Productivity Differentials}

In this section we use the panel aspects of our data to quantify differences between Korea and Taiwan in the rates of plant turnover and the relationship between plant productivity and the plant's status as an entrant, exit, or continuing producer. Both the Korean and Taiwanese manufacturing sectors are characterized by high simultaneous rates of plant or firm entry and exit, but much of the turnover reflects the net expansion of the manufacturing industries. $\square_{\text {For }}$

\footnotetext{
8 Patterns of firm entry and exit in Taiwan are summarized in Dahlman and Sananikone (1990), Wade (1990), and Aw, Chen, and Roberts (2001).
} 
example, the total number of manufacturing firms in Taiwan increased by 24 percent (from 110,818 to 137,428 firms) between 1986 and 1991. The corresponding figure for the period 1988-1993 in Korea is a 49 percent increase in the number of plants (from 59,732 to 88,864 plants)

\section{Industry Turnover Rates}

Net changes in the number of plants or firms mask large offsetting flows of entering and exiting firms. Similarly, the reallocation of resources and output that result from these gross flows have been found to be many times larger than net changes. magnitude of sunk entry costs, for example, because the capital intensity of the production process varies across industries, then the theoretical model outlined above predicts that, across industries, the turnover rate for producers, the simultaneous flows of firms into and out of the industry, will be negatively correlated with the level of sunk entry costs. High sunk cost industries will have both low entry and low exit rates, while industries with low entry costs will have frequent turnover of the producers in the industry. The theoretical result is one that holds in equilibrium when market demand is constant. When calculating turnover rates, the sum of the entry and exit rate, in industry data, the level of market demand is also changing inducing a net expansion or contraction in the number of firms. This is particularly true in our data for Taiwan and Korea, where the net entry rate can exceed 100 percent over 5 years for some industries.

In order to control for the net expansion or contraction of the size of the industry when calculating firm turnover, Dunne and Roberts (1991) suggest a measure of industry volatility.

\footnotetext{
9 Numerous empirical studies have documented this pattern using employment, output, and the number of firms or plants to measure entry and exit. Dunne, Roberts and Samuelson (1988) and Dunne and Roberts (1991) report net and gross flows for the number of U.S. manufacturing firms and their output; Davis, Haltiwanger, and Schuh (1996)
} 
The measure is defined as the sum of the entry rate and exit rate minus the absolute value of the net entry rate. It is a measure of the amount of producer turnover that is in excess of the amount needed to account for the change in industry size. ${ }^{0}$ All of the measures of producer flows, the entry rate, exit rate, turnover rate, and volatility rate, can be measured using either the number of producers that enter and exit or the amount of industry output or employment that the entering and exiting producers account for. Dunne and Roberts (1991) show that for U.S. data the output volatility rate tends to be stable over time for an industry but varies substantially across industries in a way that is correlated with the capital intensity of the industry. Cross-industry differences tend to reflect differences in technology, such as the capital-labor ratio in the industry, while time-series variation due to fluctuations in industry demand tend to be small with this measure. In contrast, net entry tends to vary substantially over time for an industry as demand fluctuates and is virtually uncorrelated with differences in technology across industries. For this reason we use the output volatility rate as our preferred measure of the amount of producer turnover that arises from differences in technology, including differences in the sunk cost of entry, across industries.

The output volatility rates for each industry and 5-year time period in our data are reported in Table 3. Comparing the 1986 figures for Taiwan with that in 1988 for Korea, volatility rates for Taiwan are higher than in Korea in every industry. In the three key industries (textiles, chemicals, and electric/electronics), these rates are between 1.5 and 2.5 times higher than those for Korea. With the exception of the apparel industry, a similar pattern holds when we compare the 1991 numbers for Taiwan with that in 1993 for Korea. A simple regression of

document employment flows in the U.S. and summarize similar statistics for other developed countries; Roberts (1996) summarizes employment flows in three developing countries. 
the volatility rates in Table 3 on industry dummies and country/year dummies shows that, relative to the textile industry in Taiwan in the 1981-1986 period, the apparel and fabricated metals industries have statistically significantly higher volatility. The transport equipment and chemical industries have significantly less volatility, and the plastic and electrical equipment industries have rates that are not statistically different. The year dummy for Taiwan for the 1986-1991 period is not significant but both year dummies for Korea are significantly negative. After controlling for the industry, the Korean data are characterized by less producer turnover.

Although both countries experienced high rates of output growth during the period we study, it is possible that differences in demand growth can still contribute to the differences in volatility rates between Taiwan and Korea. Other explanations focus on cost or market conditions that differ between the countries. Levy (1991) argues that the dense network of subcontractors in Taiwan helps to lower sunk entry and exit costs, in contrast to Korea where this network is significantly weaker. The higher volatility rates in Taiwan are also consistent with the results in Table 1 that report that, in contrast to Korea, a higher proportion of output is concentrated in the hands of smaller producers in Taiwan whose survival may be more sensitive to cyclical fluctuations. Finally, Pack and Westphal (1986), Levy (1991) and Rodrik (1995), have documented the importance of investment subsidies in Korea. These policies can depress turnover by subsidizing inefficient plants or industries.

\section{Productivity Differences between Failures and Survivors}

In the remainder of this section we examine whether the systematic differences in productivity across plants are correlated with transition patterns in and out of production. We

\footnotetext{
${ }^{10}$ Davis, Haltiwanger, and Schuh (1996) use this variable, defined with employment flows, as a measure of excess employment reallocation in an industry.
} 
also examine if these patterns differ between Taiwan and Korea in ways that can reflect differences in the strength of market selection forces in the two countries.

We begin by quantifying mean differences in productivity across groups of plants with different transition patterns. In order to organize our analysis, we define groups of plants based on year, entry cohort, and transition status as shown in Figure 2. Each column in the figure summarizes a census year, with the subscripts 1,2 and 3 representing the years 1981,1986 , and 1991 for Taiwan and 1983, 1988, and 1993 for Korea. Each row in the figure for Taiwan (Korea) represents a different cohort of plants: the $\alpha$ cohort comprising plants present in 1981 (1983); the $\beta$ cohort consisting of plants that first appear in 1986 (1988), and finally the $\gamma$ cohort comprising plants that first appear in 1991 (1993). Each initial cohort of plants can be further divided into those that survive ( $\mathrm{S}$ superscript) and failures (X superscript). We estimate regression equations for each industry in each country in which plant productivity is summarized with a set of 9 dummy variables representing the combinations of year $(1,2,3)$, cohort $(\alpha, \beta, \gamma)$, and exit/survival status (S, X).

Table 4 begins by comparing the mean productivity differences among cohorts of continuing and exiting plants in the same year to see if the former have higher productivity than the latter as predicted by the theoretical model. A negative coefficient means that exiting plants have lower productivity than surviving plants. Overall, of the 21 cells containing the coefficients for Taiwan, all but three are negative. None of the coefficients with positive signs is statistically significant. Thus, relative to surviving plants, plants that exit production after year $t$ have lower productivity in that year. For example, the figures in column 2 are negative for all seven industries, indicating that, in 1981, plants that will exit before 1986 have lower total factor productivity, on average, than the plants that will survive. The productivity gap varies from 3.4 
(fabricated metals) to 7.8 (textiles) percent. Similarly, the negative differentials in columns 3 and 4 imply that, plants that will survive until 1991 are more productive than plants that will not survive. The only difference is that the exit-survivor differentials are smaller in absolute value, ranging from 2 to 5 percent, indicating that as the cohort ages the productivity advantage of incumbent plants diminishes.

Columns 5 and 6 of the table report F-statistics for the hypotheses that there is no productivity differential between exiting and surviving plants and that the differential is constant across the three cohort/years combinations we observe, respectively. The hypothesis of no exit differential is rejected for all seven industries and the hypothesis that it is equal across cohorts is rejected in three of the seven industries. Overall, the results lead to the conclusion that exit is concentrated among the least productive firms in any cohort and year, a result consistent with the self-selection model.

As in Taiwan, plants in Korea that will exit before 1988 and 1993 are less productive than plants that survive. Of the 21 cells in columns 7-9, only three coefficients are positive. However, in contrast to the same industries in Taiwan, the shortfall in productivity among exiting plants is significantly larger in Korea. For example, in column 7, plants that exit production before 1988 are less productive, with the differential exceeding 10 percent in all industries except textiles. This pattern holds true in the next two columns. Of the coefficients that are statistically significant, the differential between exits and incumbent plants is always larger for Korean plants than the corresponding Taiwanese plants. ${ }^{-}$The larger productivity

\footnotetext{
11 The last two columns in Table 4 report F-statistics for the hypotheses that, in Korea, there is no productivity differential between exiting and surviving plants and that the differential is constant across the three cohort/years combinations we observe. Both hypotheses are rejected for all seven industries under study.
} 
differentials between exiting and continuing members of a cohort in Korea relative to Taiwan is consistent with weaker market selection forces in Korea that lower the survival threshold.

\section{Productivity Differences between Entrants and Incumbents}

Table 5 summarizes the difference in mean productivity between entering and incumbent plants by cohort and year. The second column reports, for Taiwan, differences in productivity in 1986 between new entrants in 1986 and firms from the 1981 cohort that survived through 1986. The third (fourth) column reports the productivity differences between new entrants in 1991 and survivors from the 1986 (1981) entry cohort. In general, the negative sign of all 21 coefficients in columns 2-4 indicates that entering cohorts are always less productive, on average, than incumbents in Taiwanese industries.

The coefficients in column 2 indicate that entrants in 1986 are between 2.1 percent and 6.6 percent less productive than incumbents. All but one coefficient is statistically significant. A very similar pattern is found for the entrants in 1991. When compared with the incumbents from the 1986 cohort (column 3), entrants are between 2.6 and 4.9 percent less productive than incumbents. Again, the coefficients of all but one industry are statistically significant. When compared with the 1981 cohort (column 4), the productivity disadvantage of the entrants ranges from 2.2 to 5.2 percent and are statistically significant for all seven industries. Thus, in general, older cohorts have higher average productivity than younger cohorts. 2 The hypothesis that entrants and incumbents are equally productive is rejected in all seven industries (column 5). The hypothesis that the difference in productivity between entrants and incumbents is constant

\footnotetext{
12 The magnitude of the productivity difference between entrants and incumbents depends on how the productivity distribution of entrants, $G(\phi)$ in the theoretical model, is altered as the entrants age. Failure and productivity improvements of the survivors transform this initial distribution as the cohort ages.
} 
across cohorts and years (column 6) is rejected in only one industry. This last result suggests that the productivity distributions of entering firms and incumbents shift over time in similar ways.

The results for Korea differ from those for Taiwan in two important ways. First, of the 21 coefficients in columns 7,8 , and 9 that summarize the difference in mean productivity between entering and incumbent plants, the majority (13) are positive. The positive sign implies that the entrants are more productive than the incumbents, however, only three of the differences are statistically significant. Second, of the 21 coefficients for Korea, more than half (12) are not statistically significant. In fact, as shown by the F statistics in column 10 , the hypothesis that entrants and incumbents in Korea are equally productive is not rejected in four of the seven industries. The hypothesis that the difference in productivity between the two groups is constant across cohorts and years is rejected only in the textile and electric/electronics industry (column 11). Overall, the evidence that market selection systematically eliminates the lower productivity members of a cohort is much weaker in Korea than Taiwan. 3

\section{Productivity Evolution of Survivors}

The final piece of evidence we examine focuses on the group of plants that survive across adjoining census years in Taiwan and Korea. The theoretical model outlined above assumes that there is persistence in a plant's productivity over time, specifically, that the distribution of future productivity, conditional on current productivity, $F\left(\phi_{t+1} \mid \phi_{t}\right)$ is strictly decreasing in $\phi_{t}$. We can examine the extent of productivity persistence in each country by comparing estimates of these distributions. To do this, we assign each plant to a productivity quartile in year $t$ based on its

\footnotetext{
13 Another explanation is that the technology in Korea is changing over time so that entering cohorts adopt more productive technologies in Korea. Comparisons across cohorts then do not hold the technology fixed.
} 
productivity in that year. We then graph the empirical distribution of productivity in year $t+1$ for plants in each of the quartiles. That is, we condition on the plant's presence in a quartile in one year and calculate the empirical distribution of future productivity for all plants in that quartile, $F\left(\phi_{t+1} \mid \phi_{j t}\right)$ where $\phi_{j t}$ represents that the plant was in quartile $j=1,2,3,4$ in year $t$.

The cumulative distributions of future productivity are graphed in Figure 3 for each country and industry. Within each graph, you move from left to right, the four cdf's each condition on a higher level (quartile) of initial productivity. Each of the graphs shows evidence of persistence in plant productivity with higher initial productivity levels leading to a lower probability of a low level of future productivity. There are two striking differences between the graphs for the two countries. First, in Taiwan the cumulative distributions across the four quartiles are more tightly concentrated together than they are in Korea. This implies that a plant's initial productivity has a larger impact on the plant's future productivity in Korea than in Taiwan. Second, the cdf's are shifted to the left in Korea relative to Taiwan. This implies that there is a greater probability of a surviving plant moving to the low-productivity tail of the distribution in Korea. This can reflect our earlier finding from Table 5 that entering plants are not at a productivity disadvantage in Korea, as they tend to be in Taiwan, and are replacing the incumbent producers.

Both of these points can be seen by calculating the value of the cdf for a specific level of current productivity. In Table 6 we report the estimates of $F\left(\phi_{t+1}=0 \mid \phi_{j t}\right)$ for each of the four quartiles. These are the probabilities that a plant in each respective quartile in year $t$ has period $t+1$ productivity less than the mean for the industry. The entries correspond to the values of the function $F(\cdot)$ evaluated at zero on the horizontal axis in Figure 3. Table 6 shows, for example, in the Taiwanese textile industry the probability that a plant in the lowest productivity quartile in 
year $t$ (quartile 1) has productivity less than the mean in year $t+1$ is .638 . For plants that begin in the highest productivity quartile (quartile 4), this probability is much lower, at .333 .

The more important role for initial productivity in Korea can be seen by noting the drop in the probabilities as we move from the $1^{\text {st }}$ to $4^{\text {th }}$ quartile in each row of the table. For the textile industry the probability of being below the mean drops by $.305(=.638-.333)$ as we move from the least to most productive quartile in Taiwan, while the same decline is $.523(=.876-.353)$ in Korea. This pattern is present in every industry with the decline varying from .144 to .386 across the Taiwanese industries and .292 to .523 in Korea. Finally, the fact that Korean plants are more likely to move into the low-productivity tail of the distribution than plants in Taiwan can be seen by comparing the cells in Table 6 for a given industry/quartile across countries. The higher probabilities for the Korean plants imply a greater likelihood that the surviving plants have less than mean productivity in the future and this is true even for plants that begin in the highest productivity $\left(4^{\text {th }}\right)$ quartile of the distribution.

One way to characterize the results from Figure 3 and Table 6 is that the process of productivity evolution for surviving producers in Korea, relative to Taiwan, involves a much more significant role for a plant's initial productivity in determining future success. A plant's movements through the productivity distribution are more likely to be downward in Korea than in Taiwan, regardless of starting position. This, in turn, should lead to more failure among Korean plants but, as shown in Table 4, failing plants in Korea have a larger productivity disadvantage relative to survivors than in Taiwan. This suggests that there is some impediment, possibly a sunk cost or possibly a policy-induced incentive, that makes it profitable for the producer to remain in operation. 14

\footnotetext{
${ }^{14}$ Further support that there is a weaker link between productivity and market transitions in Korea is provided by Aw, Chung, and Roberts (2000). We focus on the group of surviving plants and study their transitions in and out of
} 


\section{Summary and Conclusion}

In this paper, we use micro panel data from the census of manufactures for Taiwan and Korea to examine the relationship between productivity, size, and turnover for producers in seven two-digit industries. Our empirical study reveals a set of differences between the two countries that are very robust across the seven industries. Compared to Taiwan, Korean industries have lower rates of producer turnover, larger cross-sectional dispersion in plant productivity, a higher percentage of plants operating at low productivity levels but a higher percentage of output attributable to high-productivity plants. Introducing information on the entry or exit status of the plant reveals that productivity differentials between exiting and incumbent plants are much larger in Korea than Taiwan. Entering plants in Korea do not appear to operate at any productivity disadvantage, on average, when compared to incumbents. In contrast, in Taiwan the average productivity of entering cohorts is significantly less than the incumbents. Finally, if we focus on just the surviving plants in a cohort over time and condition on their initial productivity level, Korean plants are more likely to remain in or move into the low-productivity tail of the distribution than their counterparts in Taiwan.

All of these patterns are consistent with some impediment to exit or entry that weakens market selection forces and results in the survival of more low-productivity producers in Korea than in Taiwan. As demonstrated by Hopenhayn's (1992) theoretical model, large sunk entry costs are one such impediment. By making entry more costly, these costs reduce the flow of new producers and lower the level of productivity needed for incumbents to earn positive expected profits. This makes it easier for low-productivity incumbents to survive, reduces the amount of

the export market. In Taiwan, we find that plants entering the export market are significantly more productive and exits are significantly less productive than the group of plants that do not make the transition. This pattern holds in all industries and is consistent with productivity-based selection into the export market. In Korea, the pattern is much weaker. In three of five industries, export market entrants are significantly more productive than nonentrants. 
exit, and results in an industry characterized by a higher proportion of low-productivity producers. Only the lowest productivity plants would find it optimal to exit, leading to large productivity differentials between exiting and incumbent plants. Finally since the incumbent cohorts are subject to less market selection over time they are less likely to improve, leading to smaller productivity differentials between incumbents and entrants.

Entry costs may be higher in Korea than in Taiwan because the less-developed network of subcontractors leads to more internal production and higher initial investment expenditures. An alternative explanation for the patterns we observe may be a greater reliance on nonmarket allocation of capital in Korea. Pack and Westphal (1986) and Rodrik (1995) have discussed the importance of investment subsidies to Korean firms in the 1980s. These policies often resulted in the channeling of credit at negative real rates of interest to Korea's conglomerates. Any factor that distorts the linkage between underlying productivity and future profitability may weaken market selection forces, reduce entry and exit, and promote the survival of low-productivity producers.

While Korea and Taiwan have both experienced considerable success with their manufacturing sector development in recent decades, the micro data we analyze reveal some distinct differences in performance, particularly in the productivity differentials between entering, exiting, and incumbent producers. Do these micro patterns characterize other countries? We can point to some comparable evidence from several recent empirical studies that have quantified how firm entry, growth, and exit contribute to sectoral or aggregate productivity growth. These papers include Baily, Hulten, and Campbell (1992) and Foster, Haltiwanger, and Krizan (2001a) for the U.S. manufacturing sector, Foster, Haltiwanger, and Krizan (2001b) for productivity are determinants of the export decision for Korean plants. 
the U.S. retail sector, Olley and Pakes (1996) for the U.S. telecommunications industry, Tybout (1996) and Liu and Tybout (1996) for Chile and Colombia, Griliches and Regev (1995) for Israel, and Aw, Chen, and Roberts (2001) for Taiwan. All of these papers find that the expansion of relatively high-productivity incumbents and the contraction of relatively lowproductivity incumbents contribute to sectoral productivity growth. The role of entry and exit is less robust. The studies for the U.S. and Taiwan find that the exit of inefficient producers and the entry of new producers make a positive contribution to sectoral productivity growth because the entering producers are more productive than the exiting ones. For the other countries, entry and exit have little effect because both groups account for very little industry output or the productivity differential between the two groups is quite small.

We can also make some direct comparisons of the productivity differentials between Taiwan, Korea, and the U.S. manufacturing sector using results in Foster, Haltiwanger, and Krizan (2001a). They report that the average difference in multifactor productivity between exiting and surviving plants is -4.0 percent. On the entry side, they find that, on average, there is a 0.3 percent difference between entering and incumbent plants. ${ }^{5}$ Using our data, the estimates of the average exit differential for Taiwanese and Korean plants is -3.5 percent and -6.8 percent, respectively. The entry differential is -3.6 percent in Taiwan and 1.1 percent in Korea. 6 The summary statistics for the U.S. fall between those of Taiwan and Korea. The pattern is consistent with strong competitive pressures in Taiwan that lead to vigorous market selection. Plants exit even when their productivity disadvantage is relatively small and incumbent cohorts improve, relative to entrants, because of this attrition. Higher entry barriers in the other two

\footnotetext{
15 Table 8.12. These are the average of their estimates for three different five-year intervals.
} 
countries, particularly Korea, insulate some lower productivity producers from exit pressure and require entrants to have a larger productivity advantage over incumbents before entry is profitable.

16 These are from a regression that pools the seven industries in each country and includes dummies for industry, year, exit status, and entrant status as independent variables. 
Appendix: Construction of Plant-Level Output, Inputs, and Productivity

To construct the index of total factor productivity $\ln T F P_{t}^{i}$ defined in the text we need to construct output, input, and cost-share variables for each plant-year observation. The value of plant output is measured as the sum of total revenues from sales, repairing and fixing services, the revenue from performing subcontracted work, and the change in inventory of final goods between the beginning and end of the year. The value of output is deflated by a producer price index defined at the 2-digit industry level.

In our analysis, each producer uses four inputs in production: labor, capital, intermediate materials, and subcontracting services. The labor input is measured as the number of production and non-production workers. Total payments to labor are measured as total salaries to both groups (unfortunately, these do not include fringe benefits and pensions). The cost share of labor is the ratio of total payments to labor to the value of plant output.

The capital input is estimated as the book values of tangible assets, including building, machinery, tools, and transport equipment at the beginning of the year. To control for price level changes in new capital goods, using the 1988 book values (1986 in Taiwan) as the basis, we deflate the changes in each plant's book values between the censuses by the producer price indices for capital goods. By adjusting these deflated changes to the 1988 book values, we scale the 1983 and 1993 (1981 and 1991 in Taiwan) book values of capital goods to the 1988 basis. The cost share of capital is measured as the residual after subtracting the shares of labor, material, and subcontracting services.

The material input includes raw materials, fuel, and electricity used by the plant. Expenditures on raw materials are deflated by the producer price index for manufacturing raw materials. Fuel expenditures are deflated by an energy producer price index, and electricity expenditures are deflated by an electricity producer price index. The cost share of materials is the ratio of total expenditures on intermediate materials to the value of plant output. The cost incurred for the work that is subcontracted out to other plants is included as an input expenditure since it comprises the principle's payments to subcontractors for the labor, capital services, and expenditures on fuel and electricity by the latter. These costs are deflated by the producer price index of the industry to construct a subcontracting input. The cost share of subcontracting services is the ratio of the principle's payments to the plant's output value. 


\section{References}

Aw, Bee Yan, Xiaomin Chen, and Mark J. Roberts (2001), "Firm-Level Evidence on Productivity Differentials, Turnover, and Exports in Taiwanese Manufacturing." Journal of Development Economics, 66, 51-86.

Aw, Bee Yan, Sukkyun Chung, and Mark J. Roberts (2000), "Productivity and Turnover in the Export Market: Micro Evidence from the Republic of Korea and Taiwan." World Bank Economic Review, 14, 65-90.

Baily, Martin Neil, Hulten, Charles and Campbell, David (1992), "Productivity Dynamics in the Manufacturing Plants," Brookings Papers on Economic Activity: Microeconomics 1992, 187-267.

Caves, Douglas W., Laurits Christensen, and Erwin Diewert (1982), "Output, Input, and Productivity Using Superlative Index Numbers," Economic Journal, 92, 73-96.

Dahlman, C. and O. Sananikone (1990), "Technology Strategy in the Economy of Taiwan: Exploiting Foreign Linkages and Investing in Local Capability," mimeo, The World Bank, Washington, D.C.

Davis, Steven J., John C. Haltiwanger, and Scott Schuh (1996), Job Creation and Destruction, MIT Press.

Dunne, Timothy, Mark J. Roberts, and Larry Samuelson (1988), "Patterns of Entry and Exit in US Manufacturing Industries," The Rand Journal of Economics, 19, 495-515.

Dunne, Timothy and Mark J. Roberts (1991), "Variation in Producer Turnover Across U.S. Manufacturing Industries," in P.A. Geroski and J. Schwalbach (eds.) Entry and Market Contestability, Basil Blackwell Ltd., 187-203.

Ericson, Richard and Ariel Pakes (1995), "Markov-Perfect Industry Dynamics: A Framework for Empirical Work." Review of Economic Studies, 62, 53-82.

Feenstra, Robert C., Gary G. Hamilton, and Deng-Shing Huang (2001), "The Organization of the Taiwanese and South Korean Economies: A Comparative Equilibrium Analysis", in James Rauch and Alessandra Casella (eds.), Networks and Markets, Russell Sage.

Feenstra, Robert C., Tzu-Han Yang and Gary G. Hamilton (1999), "Business Groups and Product Variety in Trade: Evidence from South Korea, Taiwan and Japan," Journal of International Economics, 48, 71-100.

Foster, Lucia, John Haltiwanger, and C.J. Krizan (2001a), "Aggregate Productivity Growth: Lessons for Microeconomic Evidence," in E. Dean, M. Harper, and C. Hulten (eds.), New Contributions to Productivity Analysis, University of Chicago Press. 
Foster, Lucia, John Haltiwanger, and C.J. Krizan (2001b), "The Link Between Aggregate and Micro Productivity Growth: Evidence from Retail Trade.” Working Paper.

Good, David H., M. Ishaq Nadiri, and Robin Sickles (1997), "Index Number and Factor Demand Approaches to the Estimation of Productivity," in H. Pesaran and P. Schmidt (eds.) Handbook of Applied Econometrics: Microeconometrics, Vol.II. Blackwell, Oxford.

Grilliches, Zvi and Haim Regev (1995), "Firm Productivity in Israeli Industry, 1979-1988," Journal of Econometrics, 65, 175-203.

Hopenhayn, Hugo (1992), "Entry, Exit, and Firm Dynamics in Long-Run Equilibrium.” Econometrica, 60, 1127-50.

Jovanovic, Boyan (1982), "Selection and the Evolution of Industry." Econometrica, 50, 649-670.

Krugman, Paul (1994), "The Myth of Asia's Miracle," Foreign Affairs, November/December 1994, $62-78$.

Lambson, Val E. (1991), "Industry Evolution With Sunk Costs and Uncertain Market Conditions," International Journal of Industrial Organization, 9, 171-196.

Levy, Brian (1991), "Transactions Costs, the Size of Firms and Industrial Policy: Lessons from a Comparative Case Study of the Footwear industry in Korea and Taiwan," Journal of Development Economics, 34, 151-178.

Levy, Brian and W.J. Kuo (1991), “The Strategic Orientation of Firms and the Performance of Korea and Taiwan in Frontier Industries," World Development, 19, 363-374.

Liu, Lili and Tybout, James R. (1996), "Productivity Growth in Chile and Columbia: The Role of Entry, Exit, and Learning," in Industrial Evolution in Developing Countries, edited by Mark J. Roberts and James R. Tybout, Oxford University Press.

Martins, J.O. (1992), "Export Behaviour with Differentiated Products: Exports of Korea, Taiwan and Japan to the U.S. Domestic Market," in M.G. Dagenais, D.A. Nuet (eds.), International Trade Modeling. Chapman and Hall.

Olley, G. Steve and Ariel Pakes (1996), “The Dynamics of Productivity in the Telecommunications Equipment Industry," Econometrica, 64, 1263-1297.

Pack, Howard (1992), "New Perspectives on Industrial Growth in Taiwan," in Gustav Ranis (ed.), Taiwan From Developing to Mature Economy, Westview Press.

Pack, Howard and Larry Westphal (1986), "Industrial Strategy and Technical Change: Theory versus Reality,” Journal of Development Economics, 22(1): 87-128. 
Page, John (1994), “The East Asian Miracle: Four Lessons for Development Policy,” NBER Macroeconomics Annual 1994, Cambridge, MA: MIT Press.

Roberts, Mark J. (1996), “Employment Flows and Producer Turnover,” in Roberts, M.J., Tybout, J.R. (Eds.), Industrial Evolution in Developing Countries: Micro Patterns of Turnover, Productivity, and Market Structure. Oxford University Press, New York, NY, 18-42.

Rodrik, Dani (1993), "Industrial organization and product quality: evidence from South Korean and Taiwanese exports," in P. Krugman and A. Smith (eds.), Empirical Studies of Strategic Trade Policy. University of Chicago and NBER, Chicago, 195-210.

Rodrik, Dani (1995), "Getting Interventions Right: How South Korea and Taiwan Grew Rich," Economic Policy, 20, 55-107.

Tybout, James R. (1996), "Heterogeneity and Productivity Growth: Assessing the Evidence," in Industrial Evolution in Developing Countries: Micro Patterns of Turnover, Productivity, and Market Structure, Mark J. Roberts and James R. Tybout (eds.), Oxford University Press.

Wade, Robert. (1990), Governing the Market: Economic Theory and the Role of the Government in East Asian Industrialization, Princeton University Press, Princeton, New Jersey.

World Bank (1993), The East Asian Miracle: Economic Growth and Public Policy, Oxford: Oxford University Press for the World Bank. 


\section{Table 1}

Distribution of Gross Output by Employment Categories

\begin{tabular}{|l|c|c|}
\hline & $\begin{array}{c}\text { Taiwan } \\
\mathbf{( 1 9 8 6 )}\end{array}$ & $\begin{array}{c}\text { South Korea } \\
\mathbf{( 1 9 8 8 )}\end{array}$ \\
\hline Textiles & .235 & .193 \\
5-99 workers & .400 & .223 \\
100-499 workers & .365 & .553 \\
500+ workers & & \\
\hline Apparel & .340 & .285 \\
5-99 workers & .401 & .383 \\
100-499 workers & .259 & .332 \\
500+ workers & & \\
\hline Chemicals & .430 & .140 \\
5-99 workers & .233 & .361 \\
100-499 workers & .337 & .499 \\
500+ workers & .324 & .352 \\
\hline Plastics & .342 & .263 \\
5-99 workers & .334 & .385 \\
100-499 workers & & .330 \\
500+ workers & .640 & .352 \\
\hline Fabricated Metals & .272 & .317 \\
5-99 workers & .088 & .105 \\
100-499 workers & & .168 \\
500+ workers & .184 & .727 \\
\hline Electrical Machinery/Electronics & .262 & .870 \\
5-99 workers & .554 & .237 \\
100-499 workers & .538 & \\
500+ workers & & \\
\hline Transport Equipment & & \\
5-99 workers & & \\
100-499 workers & & \\
500+ workers & & \\
\hline
\end{tabular}




\section{Table 2}

\section{Cross-Sectional Productivity Dispersion}

(average values over three census years)

\begin{tabular}{|c|c|c|}
\hline Industry & $\begin{array}{c}\text { Taiwan } \\
(1981-1991)\end{array}$ & $\begin{array}{c}\text { South Korea } \\
(1983-1993)\end{array}$ \\
\hline \multicolumn{3}{|l|}{ Textiles } \\
\hline Standard Deviation & .266 & .380 \\
\hline Range $\left(10^{\text {th }}-90^{\text {th }}\right.$ Percentile $)$ & .635 & .893 \\
\hline Mean TFP Growth & .159 & .095 \\
\hline \multicolumn{3}{|l|}{ Apparel } \\
\hline Standard Deviation & .273 & .376 \\
\hline Range $\left(10^{\text {th }}-90^{\text {th }}\right.$ Percentile $)$ & .643 & .910 \\
\hline Mean TFP Growth & .039 & .217 \\
\hline \multicolumn{3}{|l|}{ Chemicals } \\
\hline Standard Deviation & .193 & .013 \\
\hline Range $\left(10^{\text {th }}-90^{\text {th }}\right.$ Percentile $)$ & .255 & 400 \\
\hline Mean TFP Growth & .576 & .936 \\
\hline \multicolumn{3}{|l|}{ Plastics } \\
\hline Standard Deviation & .237 & .314 \\
\hline Range $\left(10^{\text {th }}-90^{\text {th }}\right.$ Percentile $)$ & .553 & .713 \\
\hline Mean TFP Growth & .119 & .120 \\
\hline \multicolumn{3}{|l|}{ Fabricated Metals } \\
\hline Standard Deviation & .244 & .330 \\
\hline Range $\left(10^{\text {th }}-90^{\text {th }}\right.$ Percentile $)$ & .575 & .791 \\
\hline Mean TFP Growth & .052 & .083 \\
\hline \multicolumn{3}{|l|}{ Electrical Machinery/Electronics } \\
\hline Standard Deviation & .236 & .326 \\
\hline Range $\left(10^{\text {th }}-90^{\text {th }}\right.$ Percentile $)$ & .546 & .756 \\
\hline Mean TFP Growth & .173 & .061 \\
\hline \multicolumn{3}{|l|}{ Transport Equipment } \\
\hline Standard Deviation & .240 & .310 \\
\hline Range $\left(10^{\text {th }}-90^{\text {th }}\right.$ Percentile $)$ & .550 & .722 \\
\hline Mean TFP Growth & -.020 & .115 \\
\hline
\end{tabular}


$\underline{\text { Table } 3}$

Industry Output Volatility Rates

\begin{tabular}{|l|c|c|c|c|}
\hline \multirow{2}{*}{ Industry } & \multicolumn{2}{|c|}{ Taiwan } & \multicolumn{2}{c|}{ South Korea } \\
\cline { 2 - 5 } Textiles & $1981-1986$ & $1986-1991$ & $1983-1988$ & $1988-1993$ \\
\hline Apparel & .847 & .829 & .335 & .656 \\
\hline Chemicals & 1.00 & .881 & .750 & 1.10 \\
\hline Plastics & .540 & .655 & .265 & .158 \\
\hline Fabricated Metals & .719 & .886 & .618 & .558 \\
\hline Electrical Machinery/Electronics & .602 & .640 & .370 & .454 \\
\hline Transport Equipment & .788 & .918 & .786 & .858 \\
\hline
\end{tabular}

Volatility is defined as (entry rate + exit rate) $-\mid$ entry rate - exit rate $\mid=$

2 Min(entry rate, exit rate). Entry and exit rates are measured using the value of output accounted for by the entering and exiting firms. See Dunne and Roberts (1991) or Roberts (1996) for details. 


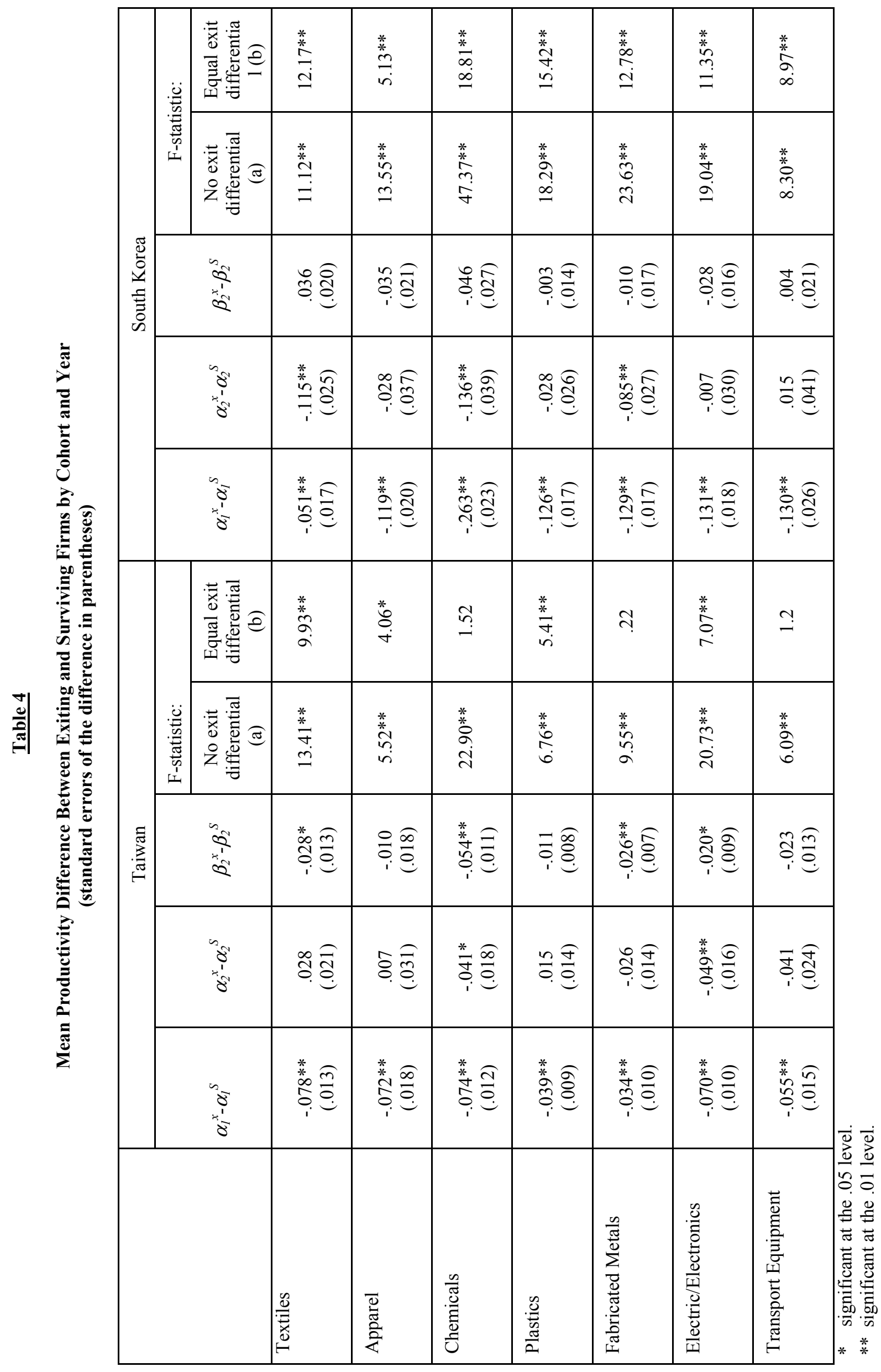




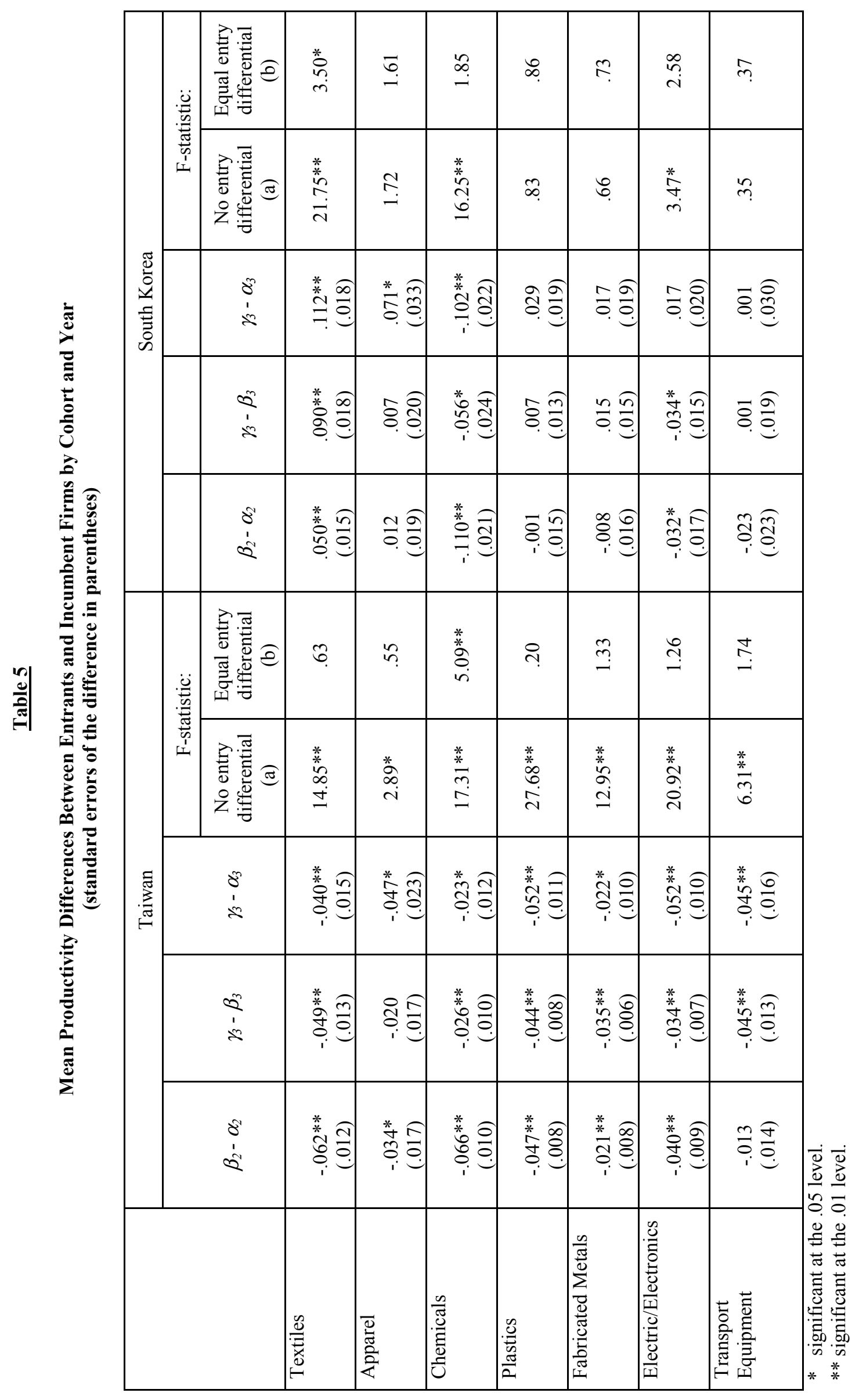


$\underline{\text { Table } 6}$

Cumulative Distribution of Current Productivity Conditional on Past Productivity

$F\left(\phi_{t+1}=0 / \phi_{t}\right)$

\begin{tabular}{|c|c|c|c|c|c|c|c|c|}
\hline & \multicolumn{4}{|c|}{$\begin{array}{c}\text { TAIWAN } \\
\text { Quartile for } \phi_{t}\end{array}$} & \multicolumn{4}{|c|}{$\begin{array}{c}\text { KOREA } \\
\text { Quartile for } \phi_{t}\end{array}$} \\
\hline & $1^{\mathrm{st}}$ & $2^{\text {nd }}$ & $3^{\text {rd }}$ & $4^{\text {th }}$ & $1^{\text {st }}$ & $2^{\text {nd }}$ & $3^{\text {rd }}$ & $4^{\text {th }}$ \\
\hline Textiles & .638 & .508 & .421 & .333 & .876 & .809 & .627 & .353 \\
\hline Apparel & .660 & .539 & .463 & .311 & .859 & .700 & .541 & .471 \\
\hline Chemicals & .654 & .512 & .420 & .268 & .836 & .689 & .551 & .340 \\
\hline Plastics & .607 & .498 & .383 & .357 & .784 & .685 & .565 & .491 \\
\hline $\begin{array}{l}\text { Fabricated } \\
\text { Metals }\end{array}$ & .548 & .483 & .412 & .334 & .846 & .686 & .574 & .412 \\
\hline $\begin{array}{l}\text { Electrical } \\
\text { Machinery }\end{array}$ & .602 & .541 & .461 & .458 & .791 & .700 & .611 & .470 \\
\hline $\begin{array}{c}\text { Transportation } \\
\text { Equipment }\end{array}$ & .632 & .516 & .408 & .394 & .789 & .685 & .560 & .497 \\
\hline
\end{tabular}


Figure 1. Cumulative Distribution of Number of Plants and Output by Productivity Level

\section{Textiles}
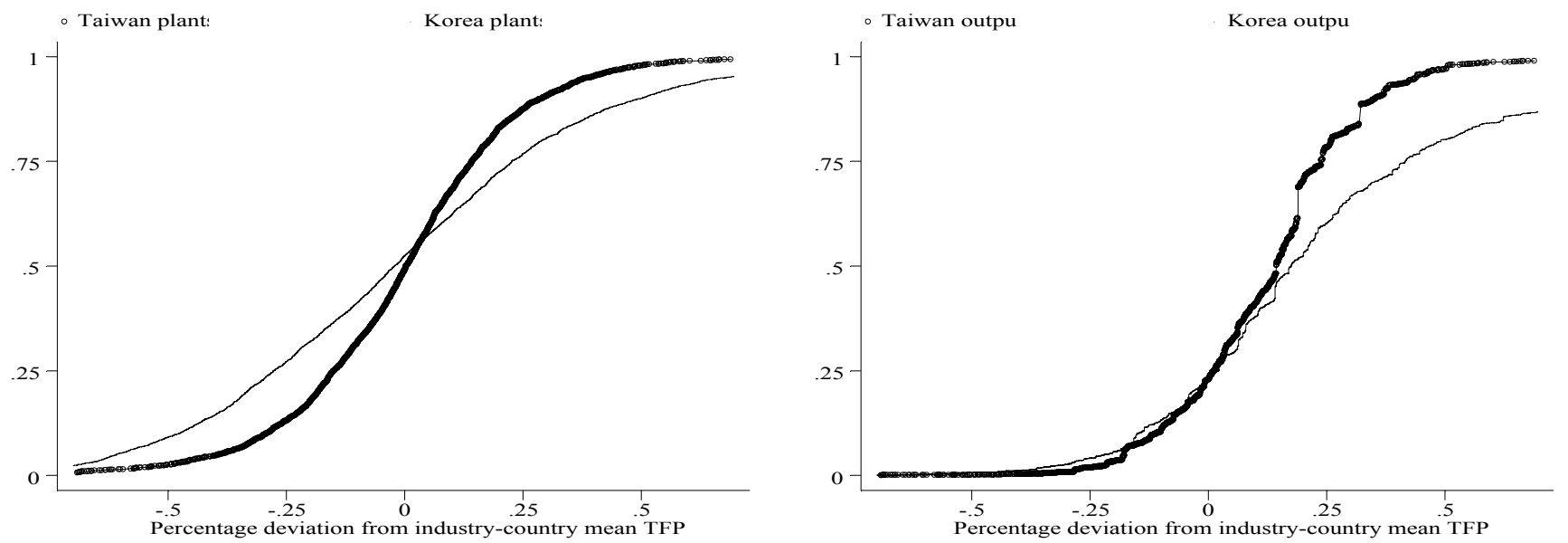

\section{Apparel}
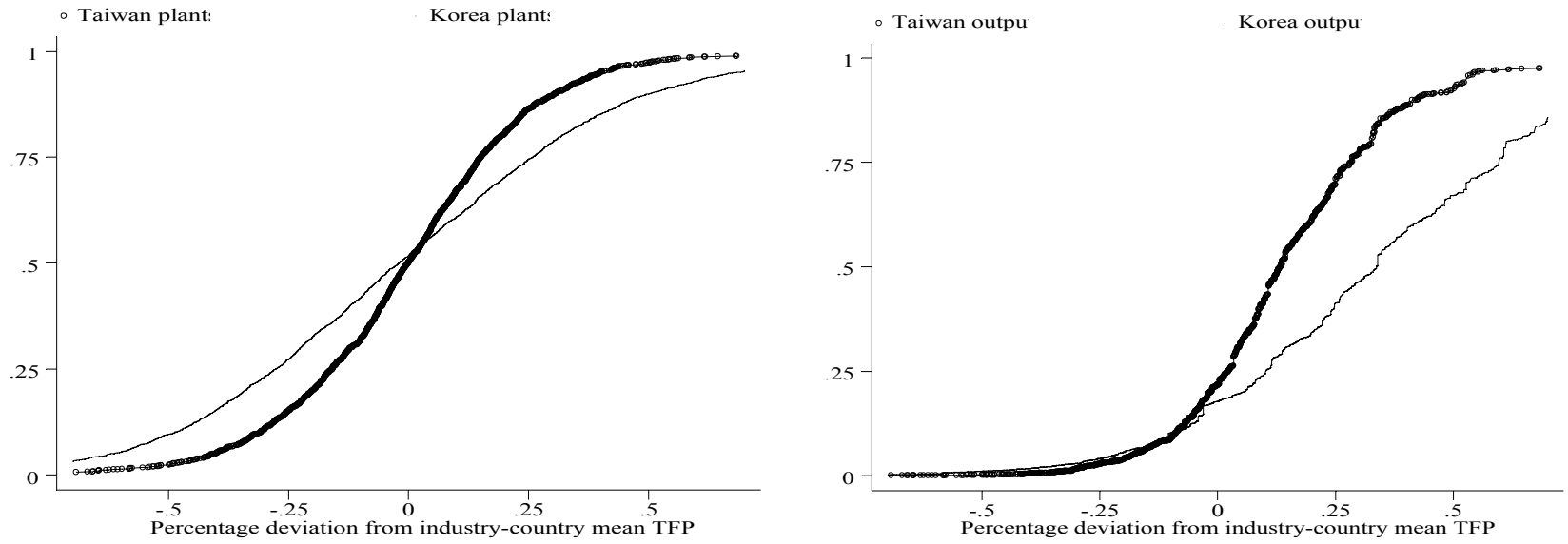


\section{Chemicals}
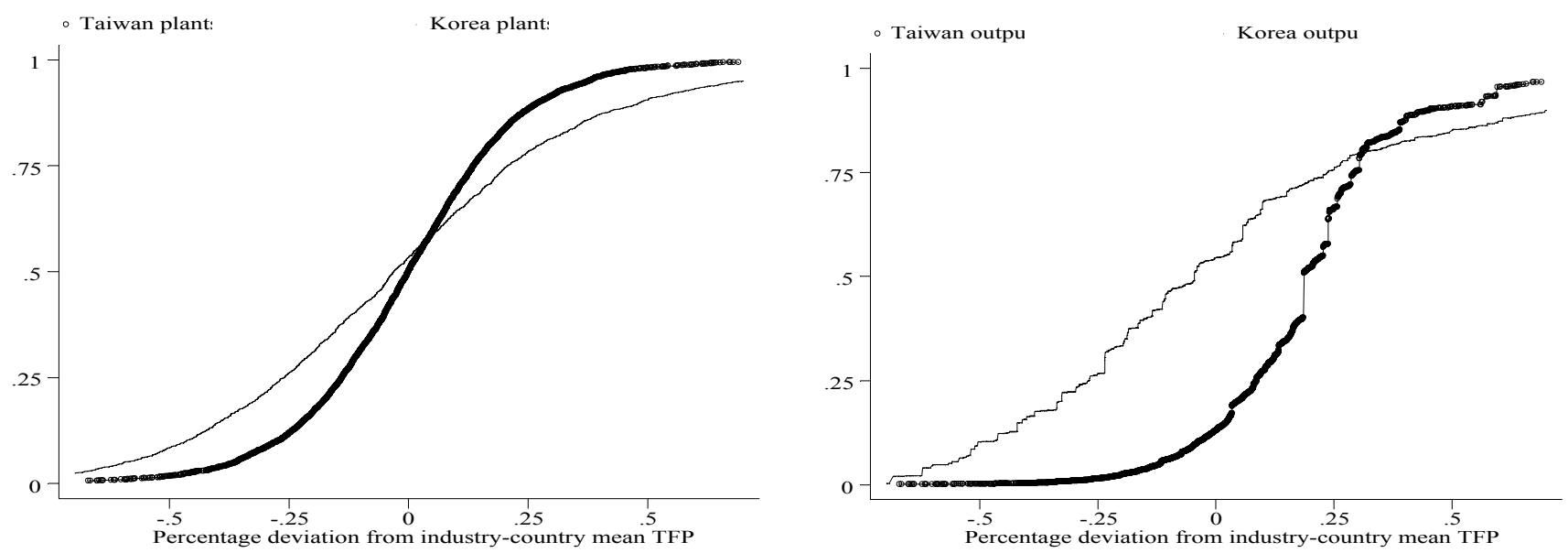

\section{Plastics}
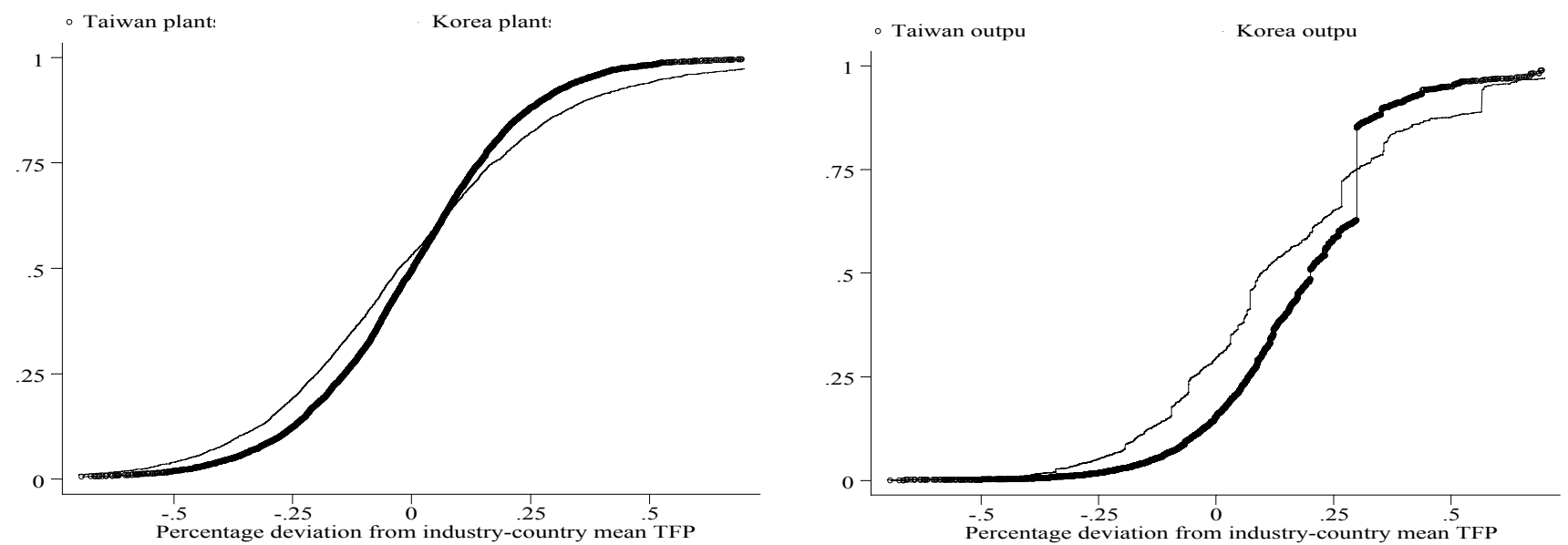


\section{Fabricated Metals}
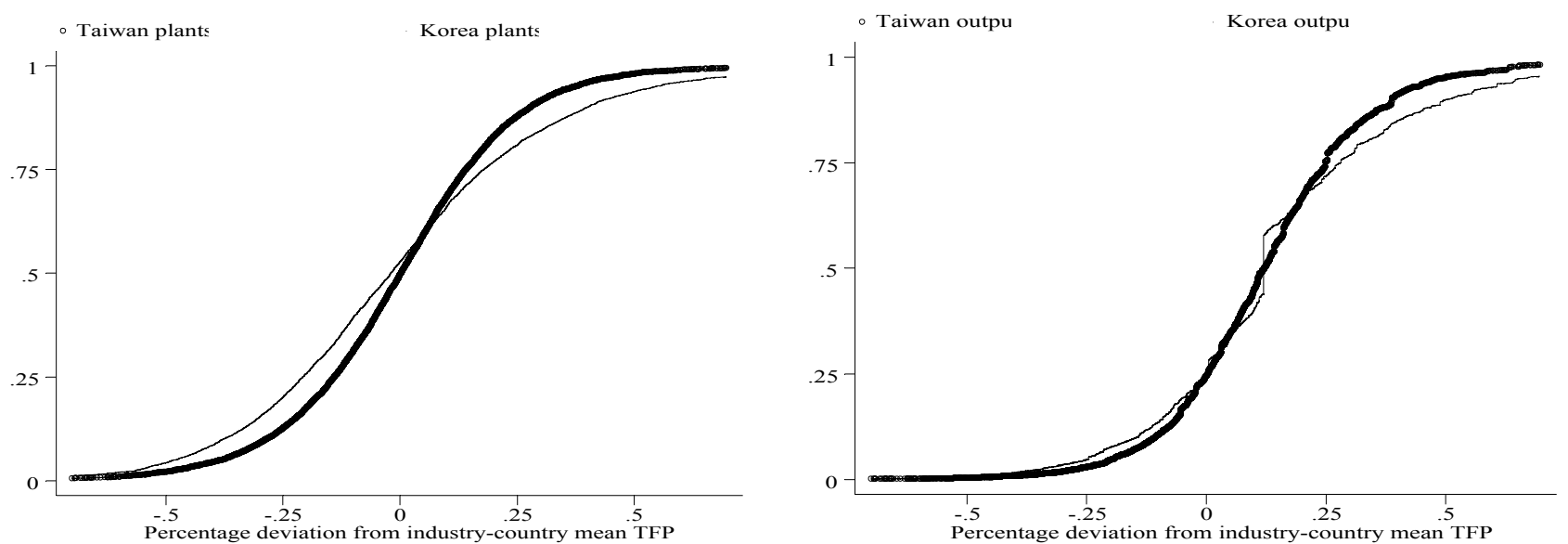

\section{Electrical Machinery and Electronics}
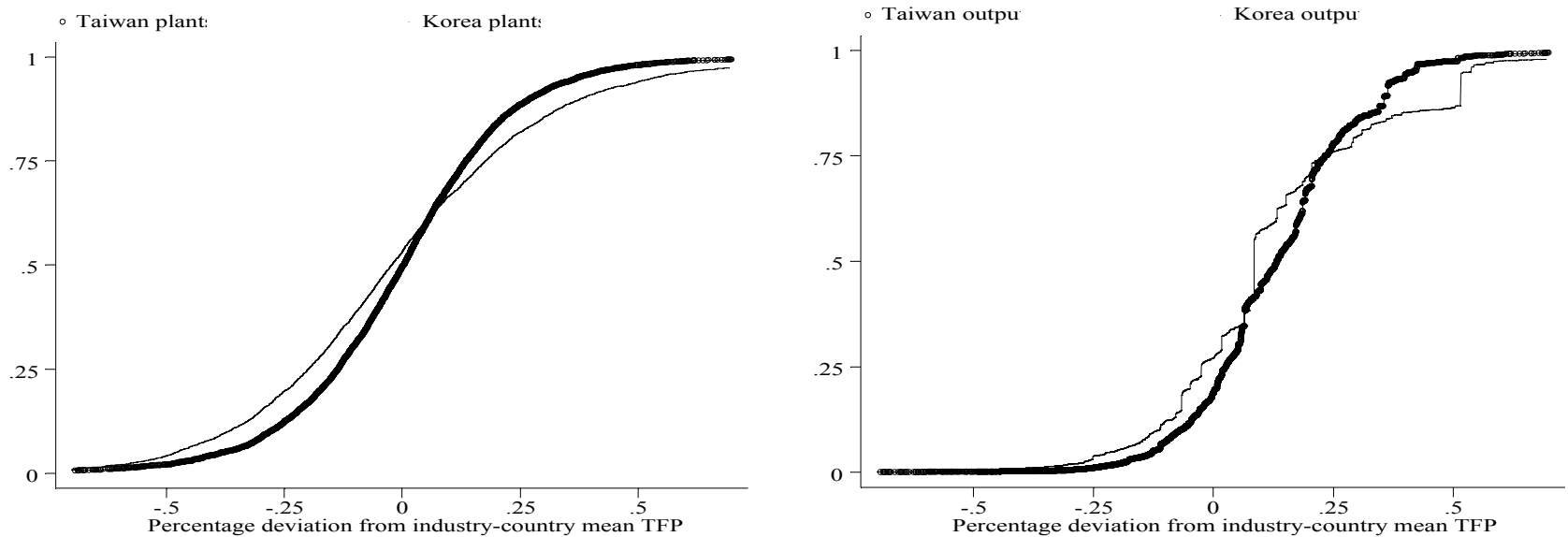


\section{Transportation equipment}
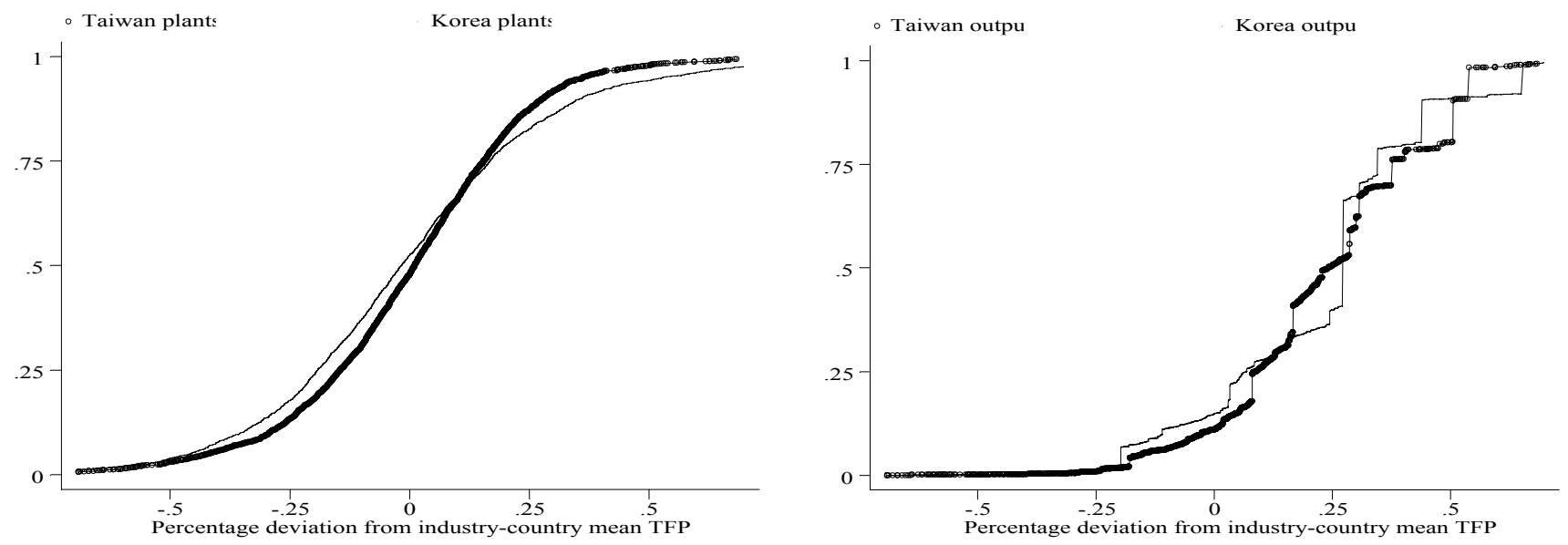
Figure 2: Plant groups based on year, entry cohort, and transition status

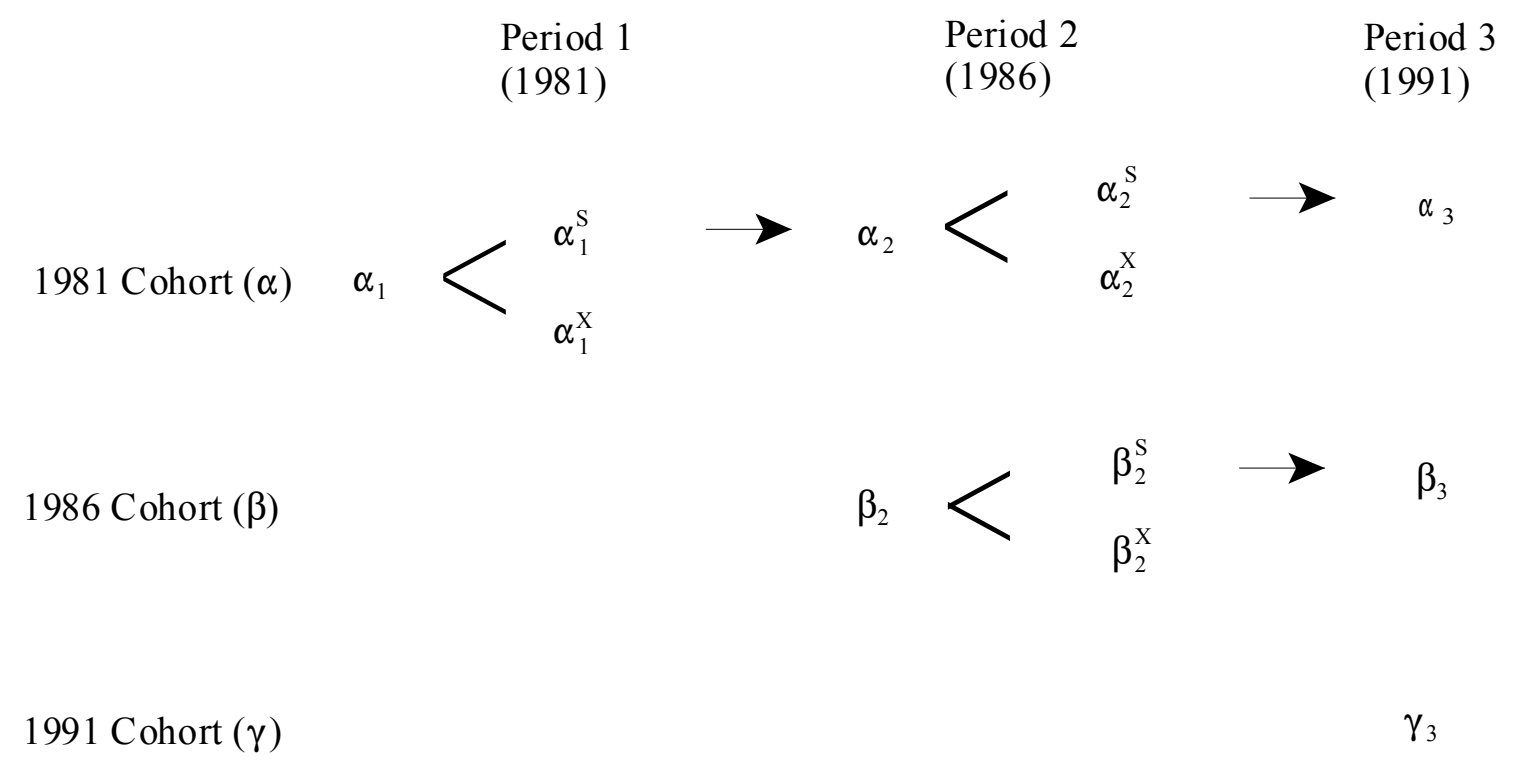

For Korea the years and cohorts are 1983, 1988, and 1993. 
Figure 3: CDF of Productivity Conditional on Prior Productivity

\section{Textiles}
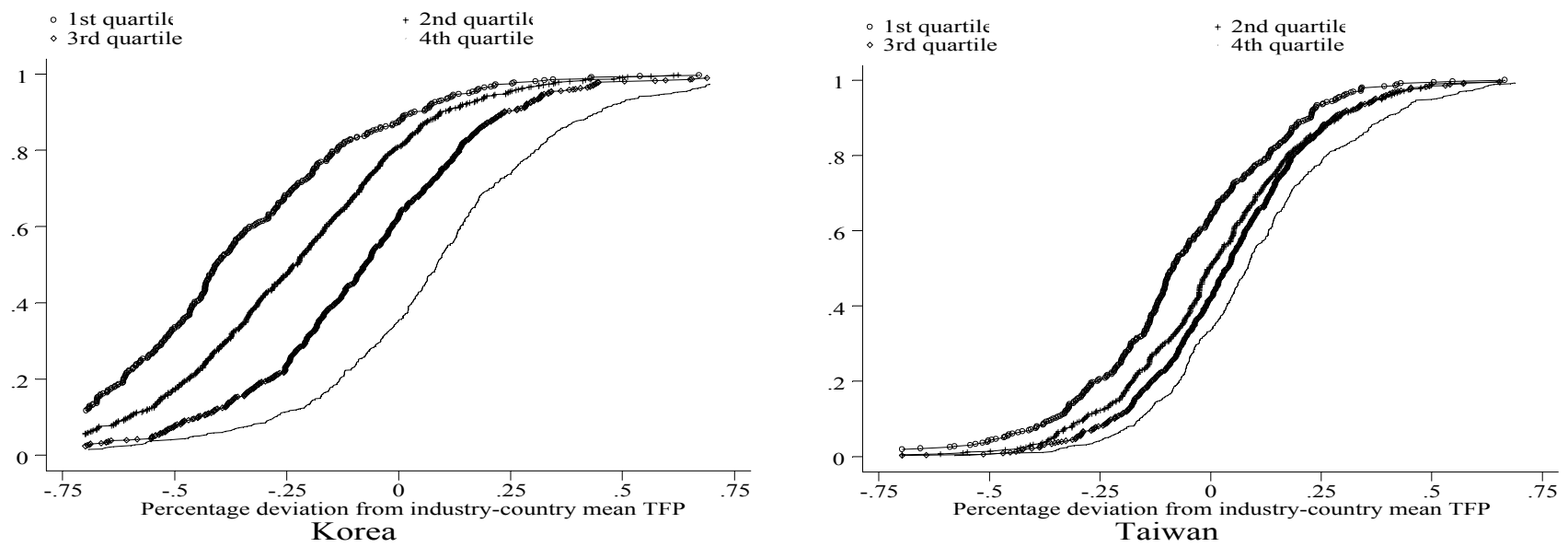

\section{Apparel}
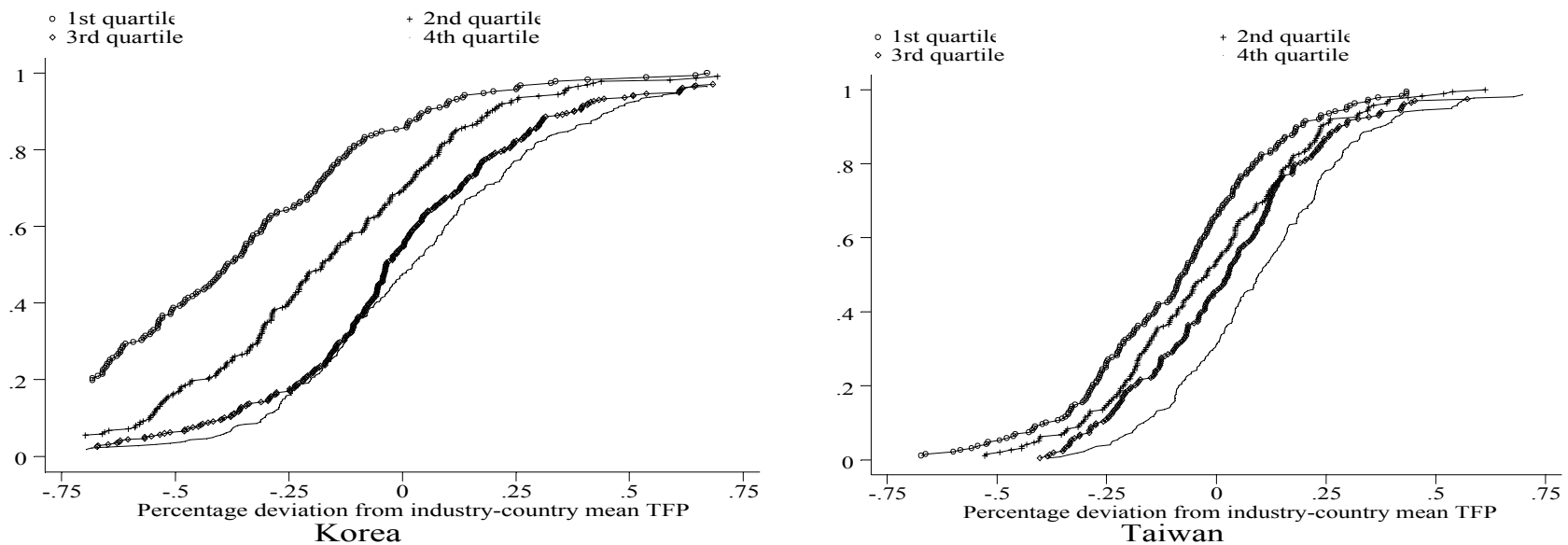


\section{Chemicals}
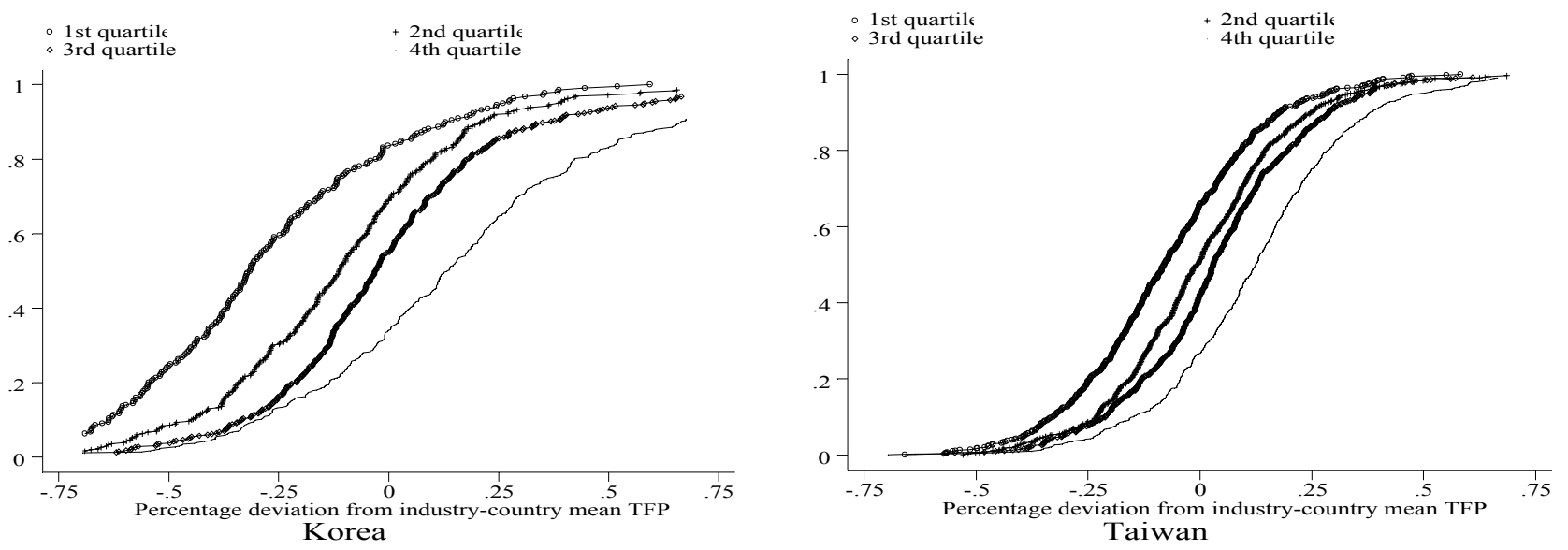

\section{Plastics}
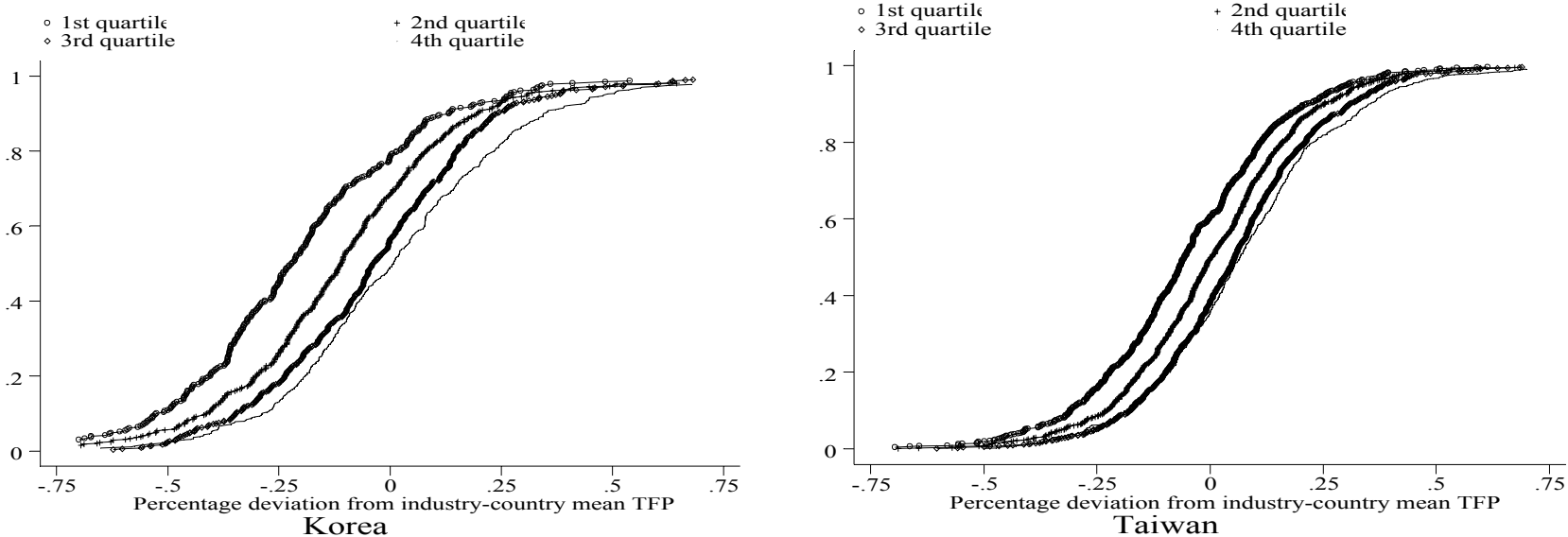


\section{Fabricated Metals}
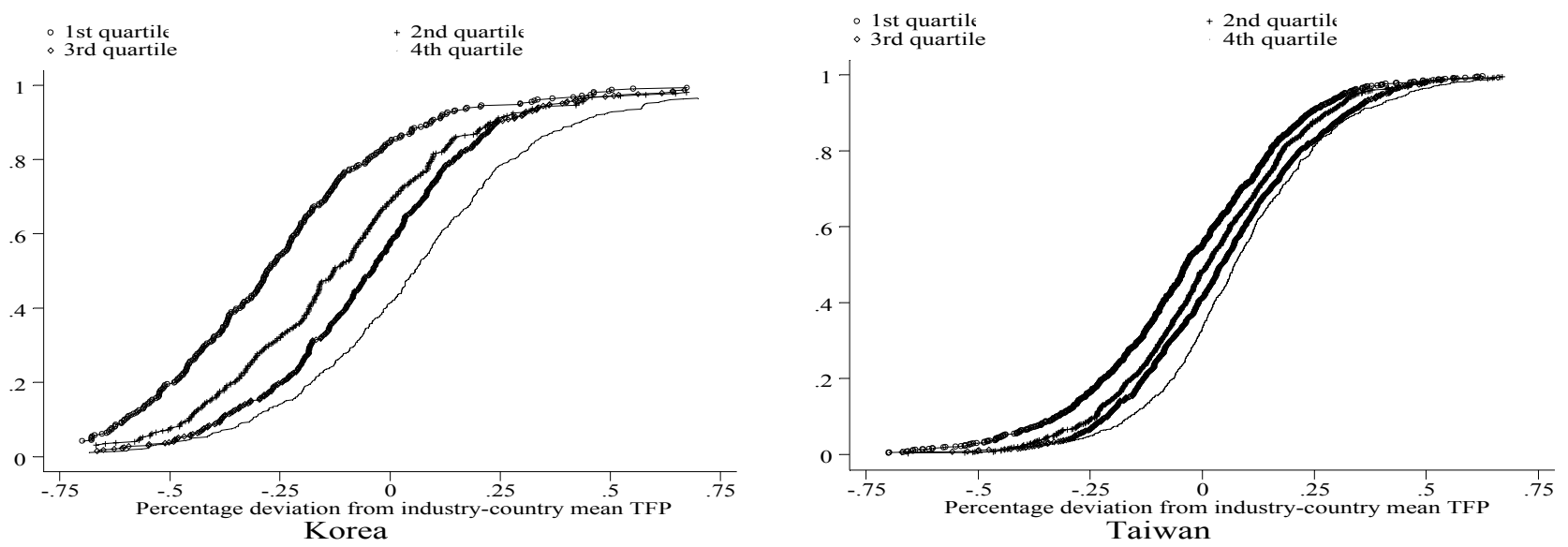

\section{Electrical Machinery and Electronics}
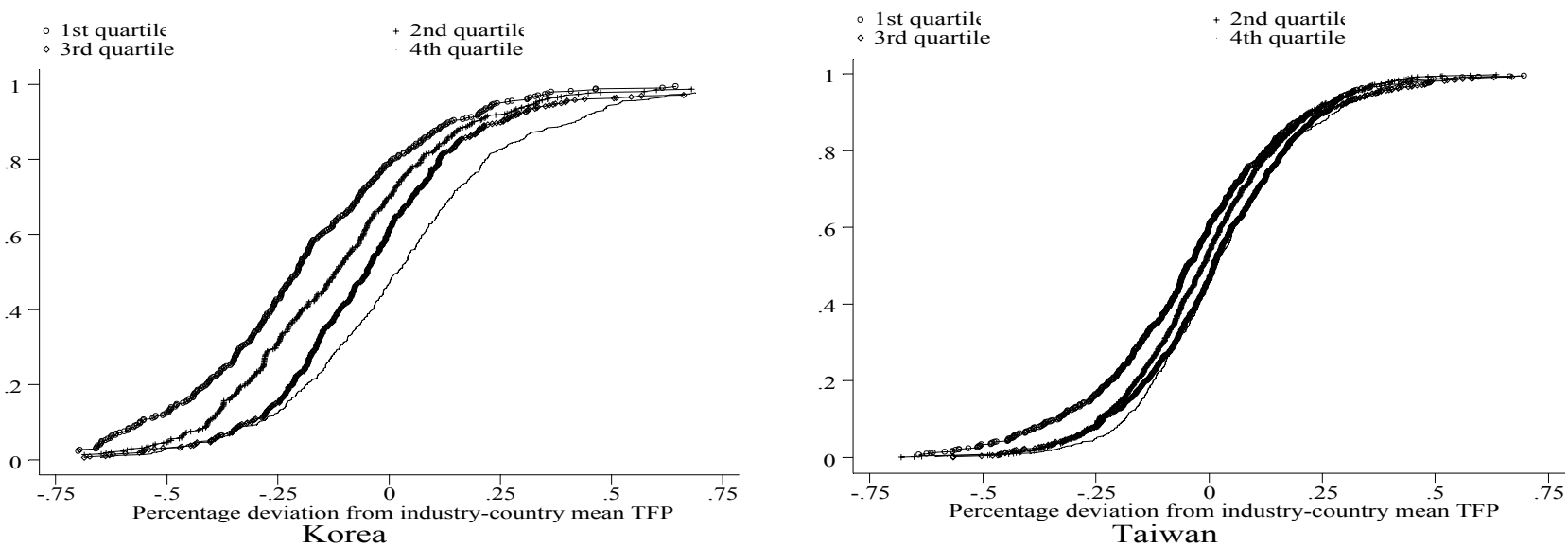


\section{Transportation Equipment}
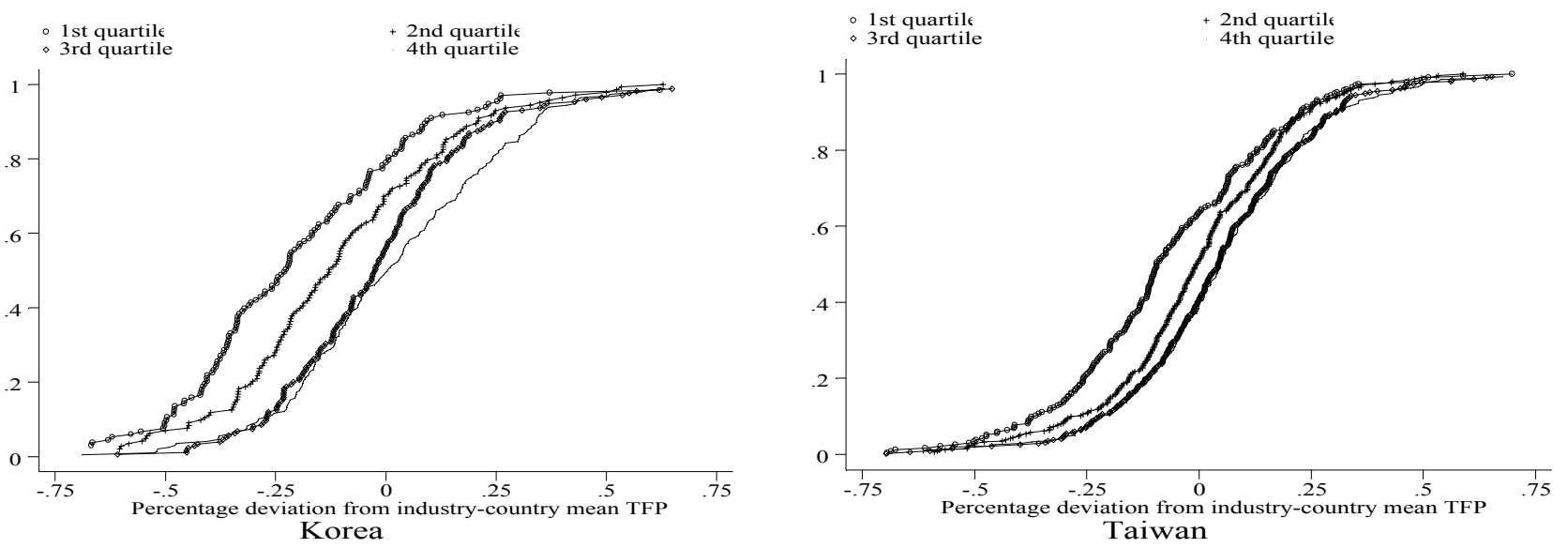